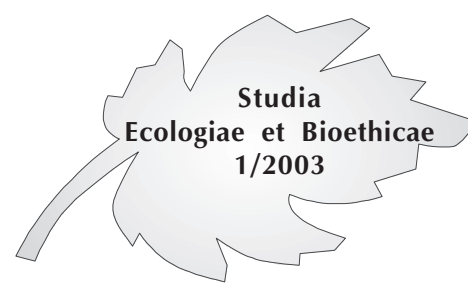

Anna SINIARSKA* i Napoleon WOLAŃSKI ${ }^{* *}$

\title{
Czym jest współczesna ekologia człowieka
}

Współcześnie słowo ekologia nabrało bardzo wielu znaczeń, stało się narzędziem użytkowym dla osiągnięcia bardzo różnych celów społecznych, politycznych a nawet fiskalnych. Przedrostek eko- stosowany bywa, aby wykorzystać ten modny termin, dla różnych celów merkantylnych, nie mających nic wspólnego z nauką, bądź dla wywarcia presji na społeczeństwo celem zdobycia środków na badania. Niekiedy są to prognozy nie oparte o rzetelne badania, lub przesadne wyolbrzymianie zagrożeń.

Słowo ekotoksykologia ma sens jako występowanie i/lub zanieczyszczenie truciznami środowiska, $\mathrm{w}$ odróżnieniu od toksykologii badającej wpływ trucizn na organizmy żywe, wywoływanych przez nie chorób oraz sposobów zapobiegania zatruciom i ich leczeniu.

Trudniej zrozumieć sens nowotworów w postaci ekofilozofii (ma sens filozofia przyrody) czy ekoteologii. Można mieć w tym zakresie nawet wątpliwości etyczne. W wielu krajach żywność produkowana bez pomocy nawozów sztucznych i pestycydów nazywana jest organiczną, w Polsce - ekologiczną. Słowo to jest nadużywane i traci swój rzeczywisty sens naukowy i społeczny. Stało się "słowem wytrychem”, które zatraciło swoje znaczenie, podobnie jak wytrych nie ma specyficznych cech klucza. Także w nauce słowo ekologia używa się obecnie niejednoznacznie. A mianowicie zarówno w celu określenia dziedziny badań ekosystemów, jak i zastosowań dotyczących ochrony przyrody (nature conservation) oraz środowiska w jakim żyjemy (environmental protection). W 1965 roku dla tych ostatnich celów Goetel i Szafer zaproponowali termin sozologia, świetnie oddający ten kierunek badań i zastosowań. Niestety termin ten się w świecie nie przyjąl, a wielu polskich badaczy ulega tendencjom nauki zachodniej, wykazując nieuzasadnione poczucie niższości. W niniejszym artykule będziemy jednak termin ten stosować, gdyż wydaje się on bardzo użyteczny i nadal warto go propagować, przy okazji wskazując na priorytet nauki polskiej $\mathrm{w}$ tym zakresie.

Departamento de Ecologia Humana, Centro de Investigacion y de Estudios Avanzados (CINVESTAV), Meksyk i Instytut Ekologii i Bioetyki, Uniwersytetu Kardynała Stefana Wyszyńskiego, Warszawa.

** Departamento de Ecologia Humana, Centro de Investigacion y de Estudios Avanzados (CINVESTAV), Meksyk. 
Owe nieporozumienia nie tylko terminologiczne dotyczą także ekologii człowieka. Stąd od co najmniej 20 lat zaczęto odróżniać ekologię człowieka jako naukę (academic human ecology) od ruchów społecznych dotyczących ochrony przyrody i środowiska (action oriented human ecology). Nazwa tego drugiego zakresu nie jest powszechnie respektowana.

Termin ekologia człowieka jest także niejednoznacznie stosowany na uniwersytetach. W niektórych z nich istnieje kierunek studiów zwany ekologią człowieka (np. na Wolnym Uniwersytecie w Brukseli) lub cała uczelnia poświecona specjalizacji w zakresie ekologii człowieka (np. College of the Atlantic w stanie Main, lub Institute of Human Ecology w Kalifornii, USA). Na pewnych uniwersytetach jest to kierunek studiów i badań z zakresu ochrony środowiska (ściślej środowiska życia człowieka), $\mathrm{w}$ innych wykładany jest konkretny przedmiot pod nazwą ekologia człowieka, w jeszcze innych istnieje katedra lub zakład ekologii człowieka prowadzący badania i wykłady z tego zakresu wiedzy transdyscyplinarnej. Niekiedy jest to więc nazwa uczelni lub kierunku studiów, a w innym przypadku katedry i wykładanego przedmiotu.

W zakresie ściśle naukowym termin ekologia człowieka jest stosowany względem konkretnych badań nad osobnikami i populacjami, w powiązaniu ze środowiskiem, jak też dokonywane są syntezy $\mathrm{z}$ innych dziedzin ekologii, celem zrozumienia przekształceń jakie do środowiska wnosi człowiek (antropopresji).

Co jednak istotne, nie bywa na ogół instytucji o nazwie ekologia (wyjątkiem był Instytut Ekologii PAN), w której byłby zakład czy katedra ekologii człowieka, natomiast istnieją instytucje o nazwie ekologia człowieka, w których istnieją zakłady lub mają miejsce wykłady ekologii ogólnej lub ekologii roślin i/lub zwierząt (np. na wspomnianych: Uniwersytecie w Brukseli i szeregu uniwersytetach w Unii Europejskiej czy w College of the Atlantic w USA).

Stosowanych jest $\mathrm{w}$ dodatku obecnie szereg terminów takich jak bioekologia (bowiem ekologię $\mathrm{w}$ rozumieniu badań środowiskowych uprawiają również np. geolodzy czy geografowie), oraz biologia środowiskowa. Ta ostatnia jest $\mathrm{w}$ naukach biologicznych terminem szerszym niż ekologia, bowiem obejmuje także wszelkie relacje organizmów żywych ze środowiskiem, zarówno na poziomie molekularnym i osobniczym, jak populacyjnym i biocenotycznym.

Jeszcze przed 30-40 laty ekologia jako nauka biologiczna dzieliła się na autekologię (organizm-środowisko) i populacjologię czy demekologię (populacja-środowisko oraz stosunki między gatunkami). Współcześnie bioekolodzy raczej wyłączają autekologię z ekologii, funkcjonuje ona jako odrębna dyscyplina naukowa pod nazwą fizjologia środowiskowa. Natomiast zarówno ekologia rozumiana jako nauka o interakcjach między populacjami różnych gatunków na tle warunków środowiskowych, jak i 
środowiskowe problemy rozwoju osobniczego i relacje fizjologiczne organizmów ze środowiskiem wchodzą w skład biologii środowiskowej.

Pod tym względem inne tendencje panują w ekologii człowieka, która łączy badania na poziomie osobniczym $\mathrm{w}$ aspekcie zmian zachodzących $\mathrm{w}$ ontogenezie ze zmianami zachodzącymi na poziomie populacji to jest $w$ trakcie filogenezy. Dostosowania jakie mają miejsce $w$ ontogenezie są elementem łańcucha przystosowań zachodzących w ewolucji gatunku. W sensie ekologicznym i ewolucyjnym ontogeneza jest ogniwem czy cyklem filogenezy. Przeżywają te osobniki, których przebieg rozwoju osobniczego okazuje się skuteczny w danym środowisku dla pozyskania pokarmu, obrony przed niebezpieczeństwami, a to umożliwia wydanie potomstwa i przedłużenie istnienia gatunku. Cała ontogeneza jest walką o przetrwanie jak najmniejszym kosztem energetycznym. W populacjach zbieracko-łowieckich nawet dziecko od odłączenia od piersi do 5 roku życia samo pozyskuje co najmniej połowę potrzebnego mu pożywienia oraz uczestniczy w jego przyrządzeniu. Aby dożyć do okresu rozrodu, wydać potomstwo i go wychować, wszystko to wymaga nakładów energetycznych.

Ekologia człowieka jest jednak bardzo różnie pojmowana nawet $\mathrm{w}$ poszczególnych organizacjach czy na uniwersytetach tego samego kraju. Na przykład inaczej pojmuje ją w USA Society for Human Ecology, aniżeli klasycy ekologii człowieka do których należą Paul Baker, Emilio Moran czy Michael Little z ośrodków uniwersyteckich. W Polsce inaczej poznański ośrodek antropologiczny aniżeli warszawski pierwszy w świecie ośrodek ekologii człowieka. Trudność porozumienia polega na tym, że nikt nie chce zrezygnować ze swego odrębnego pojmowania zarówno zakresu ekologii człowieka, jak nawet poszczególnych terminów używanych dla opisu zjawisk ekologicznych. Przykładem może być adaptabilność. Słowo to wg klasycznego słownika Webstera oznacza zdolność do zmian przystosowawczych ("the quality of being adaptable" [Webster's 1979, str. 21], co potwierdza Moran [1982, str. 5] "human adaptability tends to emphasize the plasticity of human response to any environment"), co nie jest niestety akceptowane przez pewną grupę ludzi zajmujących się problemami środowiska człowieka $\mathrm{w}$ aspekcie ewolucyjnym. Wprowadza to chaos terminologiczny i utrudnia porozumienie. Mogą się bowiem porozumieć ludzie mówiący różnymi językami, ale nie ludzi pod tym samym słowem rozumiejący co innego.

Kolejny problem stanowi pojęcie ekologii człowieka jako przedmiotu badań naukowych oraz jako kierunku studiów. Jako kierunek studiów ekologia człowieka sprowadza się na ogół do zestawu wykładów na temat biologii środowiskowej odniesionej do gatunku Homo sapiens (zjawiska interakcji i zmian przystosowawczych, również w aspekcie ewolucyjnym) oraz ochrony środowiska życia człowieka. Nie znane są nam nato- 
miast przypadki odrębnych wykładów z zakresu fizjologii środowiskowej. W biologii byłby to problem fizjologii porównawczej różnych organizmów na tle odmiennych warunków środowiskowych. W odniesieniu do człowieka jest to fizjologia ludzkiego organizmu na tle różnych klimatów i warunków bytowych, także w aspekcie rozwojowym (auksologia, gerontologia), oraz w warunkach ekstremalnych (bioklimatologia, fizjologia pracy, ergonomia).

Wobec tak wielu kontrowersji przedstawimy poniżej współcześnie przyjmowaną $\mathrm{w}$ świecie definicję i podział oraz historię powstania i rozwoju ekologii człowieka.

\section{Ekologia człowieka jako nauka}

Ekologia człowieka (EC) jest naukg o człowieku jako gatunku biologicznym $i$ jego kulturze, jako dynamicznym komponencie ekosystemów.

Gatunek Homo sapiens charakteryzuje się między innymi tym, że właściwa jest mu kultura. Kultura go wyodrębniła z pośród innych zwierząt, czyniąc człowiekiem. Podkreślenie roli kultury jest więc w definicji świadome, bowiem chodzi o ujęcie interdyscyplinarne, a biolodzy nie badają zjawisk kulturowych mając na uwadze gatunek ludzki. Natomiast w cytowanej definicji chodziło o zaznaczenie biologicznej i kulturowej jedności człowieka. Z kolei ekosystem podlega ciągłym przekształceniom, podkreślenie więc owej dynamicznej roli człowieka wydaje się być zbędne, jednak sformułowanie to wynika $\mathrm{z}$ faktu, że żaden inny gatunek $\mathrm{w}$ tak poważnej mierze nie wywiera swego wpływu na ekosystemy jak Homo sapiens.

Przedmiotem badań EC jest organizm człowieka i populacja ludzka w interakcji ze środowiskiem $\mathrm{w}$ jakim występuje, w szczególności biologiczne, społeczne i kulturowe powiązania ludzi ze środowiskiem ich życia.

Powyżej podana definicja, zakres zainteresowania i kompetencji ekologii człowieka są $\mathrm{w}$ niniejszym artykule przedstawione zgodnie $\mathrm{z}$ ich pojmowaniem przez Komisję Ekologii Człowieka Międzynarodowej Unii Nauk Antropologicznych i Etnologicznych (CHE/IUAES). W tym ujęciu jest ona nauką transdysciplinarną opartą o teorię systemów. Jako centrum badanego systemu przyjmuje się populację ludzką.

Głównym problemem ekologii jest interakcja organizmów żywych ze środowiskiem. W ekologii człowieka jest to interakcja między człowiekiem, a środowiskiem w jakim żyje, zarówno naturalnym (przyrodniczym) jak i społeczno-kulturowym. Człowiek jest tu pojmowany jako organizm biologiczny, osoba ludzka, populacja i społeczeństwo.

Człowiek walczy o przeżycie w środowisku dwiema drogami; (1) przez przystosowania biologiczne własnego ciała umożliwiające skuteczne istnienie i wydanie potomstwa, oraz (2) zachowania kulturowe po- 
przez (a) zabezpieczenie organizmu przed niekorzystnymi bodźcami środowiska, (b) zmianę tych warunków na korzystne lub (c) migrację na tereny o korzystnych warunkach. W pewnym sensie człowiek przez swoją kulturę walczy z siłami natury, tworząc jakościowo nowe warunki bytowania. Tworząc te warunki i korzystając z zasobów środowiska dla pozyskania żywności oraz innych surowców i energii, człowiek wpływa nie tylko na swoje bezpośrednie otoczenie, ale przekształca środowisko w większej skali. Zaburzając działanie ekosystemów, czy produkując zanieczyszczenia przenoszące się nawet na inne kontynenty stwarza zagrożenia w skali globalnej.

Wpływ populacji ludzkich na środowisko zwany jest antropopresja. Zazwyczaj każde takie oddziaływanie poza efektami oczekiwanymi, ma swoje skutki uboczne, z których cześć jest niekorzystna. Zmienione środowisko w postaci sprzężenia zwrotnego oddziałuje na człowieka. Są to skutki zamierzone oraz skutki nieoczekiwane. Te ostatnie są na ogół niekorzystne lub wręcz szkodliwe. Działają niekiedy z opóźnieniem i są trudne do powiązania z przyczynami je wywołującymi. Do tych niekorzystnych skutków zaliczyć można np. ukryte niedożywienie lub przekarmienie, zanieczyszczenia żywności, powietrza i wody, stresy emocjonalne, uczucia dyskomfortu i wywołane tymi czynnikami choroby, często prowadzące do skrócenia czasu trwania życia.

Wymienione oddziaływania człowieka na środowisko ( $w$ tym innych ludzi), oraz wpływ środowiska (w tym innych ludzi) na organizm czy grupę ludzi (rodzinę, warstwę społeczną, populację) jest niczym innym jak wspomnianą interakcją.

Etapem wstępnym do badań z zakresu ekologii człowieka jest rejestracja efektów wspomnianych interakcji przez monitorowanie zarówno stanu biologicznego populacji ludzkich, jak i stanu środowiska. W tym ostatnim zakresie w szczególności chodzi o rejestrację stanu środowiska w jakim żyje dana populacja ludzka, to jest szeroko rozumianych warunków bytowych.

Monitorowanie stanu biologicznego populacji dotyczy (1) stanu zdrowia, (2) stanu odżywienia oraz (3) sprawności reprodukcyjnej (rozrodczości i przeżywalności). Dane zbierane są za pomocą pomiarów morfologicznych, fizjologicznych, biochemicznych, wywiadu, fotografii itp. Wykorzystuje sie również metody demograficzne, szczególnie do oceny sprawności reprodukcyjnej (darwinian fitness). Sprawność reprodukcyjna ma dwa aspekty: płodność tj. produkcję nowych osobników i umieralność tj. ubywanie tych osobników których organizmy z różnych względów nie mogą już funkcjonować w danym środowisku. Syntetyczna miara sprawności reprodukcyjnej populacji, używając danych o wymieralności i płodności według wieku, mierzy prawdopodobieństwo z jakim przeciętny członek populacji może w pełni uczestniczyć w produkcji następnego pokolenia (Hen- 
neberg i Piontek 1975, Henneberg 1976). Stosowanie pojedynczych cech jako wskaźników jest kwestionowane i wskazuje się, że jedynie ich zestaw określający wszystkie wyżej wymienione trzy aspekty stanu biologicznego pozwala na trafną ocenę (Wolański i Siniarska 2001b).

Zebrane materiały opracowywane są przy pomocy metod graficznych, kartograficznych, statystyki matematycznej itp. Stosowane są więc metody zbierania i opracowania materiałów wykorzystywanych w różnych dyscyplinach szczegółowych - lecz żadna ze stosowanych metod nie jest traktowana jako nauka per se.

Badania morfologii, czynności czy procesów biochemicznych ludzkiego ciała są przedmiotem badań antropologii, fizjologii, hematologii. Badania zmian struktury populacji są przedmiotem badań genetyki i demografii populacji ludzkich.

Badania warunków środowiskowych są przedmiotem (geo)ekologii, (bio)ekologii, lecz także ekonomii. Chodzi tu zarówno o warunki fizyczne, chemiczne, biologiczne, socjalne, które jako czynniki środowiska oddziałują na ludzki organizm. Oddziałują one na organizm zarówno na drodze fizykochemicznej jak i emocjonalnej.

Badaniem kulturowych zachowań ludzkich zajmuje się etnologia (antropologia kulturowa w terminologii USA), badaniem zachowań grupowych, społecznych i funkcjonowania instytucji społecznych zajmuje się socjologia (antropologia społeczna w terminologii USA). Są to odrębne dyscypliny naukowe o określonym zakresie zainteresowań i stosowanych metodach badawczych. Pozostają takimi nawet wówczas gdy badania prowadzimy ze środowiskiem $\mathrm{w}$ tle, a więc $\mathrm{w}$ podziale na pewne typy antropologiczne, grupy etniczne czy zawodowe o konkretnej lokalizacji terytorialnej z jej właściwościami klimatycznymi, biologicznymi i ekonomicznymi.

Dopiero wówczas gdy badamy organizmy i populacje ludzkie oraz równie dokładnie warunki środowiskowe $\mathrm{w}$ jakich żyją oraz $\mathrm{z}$ zestawienia tych danych wnioskujemy o interakcji populacji ludzkich ze środowiskiem - jest to ekologia człowieka. Właściwości populacji i społeczności mogą być rejestrowane $\mathrm{w}$ postaci stanu biologicznego, zachowań kulturowych, instytucji społecznych itp. - a stan środowiska przy pomocy rejestracji klimatu, zasobów środowiskowych, warunków społeczno-ekonomicznych i innych jego charakterystyk.

$\mathrm{Na}$ pograniczu tych dyscyplin szczegółowych dotyczących miejsca jednostek i populacji ludzkich w środowisku, wyobrażeń o środowisku (siłach przyrody), świadomości (zwanej ekologiczną) tego czym jest środowisko, znajduje się politologia. Ta ostatnia zajmuje się stosunkami między warstwami czy klasami społecznymi w aspekcie zróżnicowania środowiskowego, to jest dostępu do zasobów naturalnych i warunków bytowych $w$ jakich ludzie ci żyją. Ten ostatni aspekt jest także przedmiotem zainteresowania ekologii człowieka. 
Podkreślić należy dobitnie, że to czym (bio)ekologia zasadniczo różni się od ekologii człowieka jest fakt, że w zakres tej pierwszej nie wchodzq badania nad dostosowaniami na poziomie organizmu oraz nad kulturowymi sposobami przystosowania. A te ostatnie zagadnienia są podstawą zarówno ochrony środowiska, jak środowiskowych problemów zdrowia, żywienia, planowania rodziny i dobrostanu populacji ludzkich.

\section{Ekologia człowieka a sozologia}

Gospodarowanie i wykorzystanie zasobów naturalnych jest przedmiotem badań ekonomii. Ochrona środowiska jest przedmiotem sozologii (nauki o ochronie przyrody $i$ jej zasobów). Ujęcie ochrony przyrody w rozumieniu "humanitarnej" czy "humanistycznej" ekologii, pewne grupy badaczy w Stanach Zjednoczonych nazywaja także ekologia człowieka (human ecology - Miller 1985, por. str. 104). Kierunek ten nawotuje, pod wptywem działań Ehrlichów $(1970,1977)$ i Odumów (1971, 1980), do ochrony środowiska w którym człowiek żyje („,environmental protection") $i$ ochrony ginacych gatunków zwierząt $i$ roślin ("nature conservation”). „Koncepcja ekosystemu oraz uświadomienie sobie, że ludzkość stanowi część kompleksu cykli biogeochemicznych $i$ że jej możliwości wywołania zmian w przebiegu tych cykli zwiększaja się, to podstawowe idee wspótczesnej ekologii" (Odum 1982). "Nasze wyobrażenia moralne i instytucje spowodowaty, że ludzkość znalazła się w konflikcie z prawami przyrody. Ludzka moralność $i$ instytucje będa zniszczone przez realne fakty biologiczne i fizyczne" (Ehrlich $i$ wsp. 1975). Istnieja w tym względzie liczne instytucje naukowe $i$ katedry na uniwersytetach amerykańskich, jednak na ogót nie noszq one nazwy ekologii człowieka ani ekologii (bez przymiotnika), lecz dwóch wyżej wymienionych nazw: ochrony środowiska $i$ konserwacji przyrody.

Wobec rozbieżności pojęcia ekologii człowieka między przedstawicielami nauk biomedycznych i społeczno-ekonomicznych, a także badaczami i "ochroniarzami", gdy w latach 60-tych XX wieku powotywano Międzynarodowy Program Biologiczny (IBP) i w jego ramach powstała sekcja przystosowalności człowieka (Human Adaptability) zastosowano inna nazwę dla określenia tej ostatniej dziedziny badañ, zamiast "human ecology", użyto nazwy "ecology of Man". W języku polskim mogtoby to odpowiadać terminom "ludzka ekologia" $i$ "ekologia człowieka".

Badania ginących gatunków czy zanikających kultur są pewnymi paralelami względem siebie, pierwsze są przedmiotem zainteresowania ekologii, drugie etnografii. Są to bardzo ważne problemy w skali przyszłości życia na naszej planecie. Jednak nie są to problemy ekologii człowieka jako nauki.

Natomiast problemem ekologii człowieka jest to, na ile występowanie owych wymierających gatunków zmieni środowisko życia człowieka, 
zaburzając równowagę ekosystemów, tym samym wpływając na jego organizm i strukturę populacji, oraz w jakim stopniu ginące kultury, które stanowiły sposób na życie $\mathrm{w}$ danych warunkach środowiska naturalnego i społecznego mają wartość dla przyszłości człowieka. Gdy zunifikowane w skali globalnej praktyki kulturowe epoki przemysłowej, poprzemysłowej i potechnologicznej staną się zawodne, być może trzeba będzie sięgnąć do tych, które się zachowały $\mathrm{w}$ tradycji i sprawdziły w poprzednich epokach. Podobnie jak poszczególne gatunki roślin i zwierząt stanowią unikatowe kombinacje genotypowe, unikatowymi praktykami wynikającymi z doświadczeń charakteryzują się poszczególne kultury. Zestawy genów poszczególnych gatunków zostały wyselekcjonowane w odmiennych ekosystemach, natomiast praktyki kulturowe zdecydowały o przeżyciu ludzkich społeczeństw. Badania z zakresu ekologii ewolucyjnej i behawioralnej człowieka pozwalają zrozumieć jak przystosowania biokulturowe powstawały i funkcjonowały w postaci złożonych form współżycia społeczno-kulturowego zwanych cywilizacjami.

Ekologia człowieka jest bardzo ważną podstawą naukową dla ochrony środowiska, planowania przestrzennego, urbanistyki i szeregu innych dziedzin, jako synteza wiedzy o powiązaniu populacji ludzkich ze środowiskiem. W pierwszym rzędzie chodzi o wymogi względem środowiska i wpływy zmienionego środowiska na organizm i populacje. Inżynierowie, a nawet urbaniści i inni planiści przestrzeni, nie dostatecznie znają te potrzeby i związane $\mathrm{z}$ tym wymogi co do kształtowania środowiska życia człowieka. Bioekologia takich syntez na ogół nie czyni. Właśnie tę lukę wypełnia ekologia człowieka, bowiem jednym z jej zadań jest wyjaśnianie jak populacje ludzkie zmieniają środowisko, także w sensie ekosystemów oraz jak to zmienione środowisko oddziałuje na populacje ludzkie. W tym pierwszym zakresie tworzy syntezę badań z zakresu ekologii roślin i zwierząt, w szczególności w skali krajobrazów ekologicznych. $W$ tym drugim zakresie prowadzi własne badania, bowiem współczesna bioekologia nie zajmuje się wpływem środowiska na indywidualne organizmy (fizjologią środowiskową), a jedynie na strukturę populacji i zespołów populacji różnych gatunków.

Wpływ środowiska na indywidualne organizmy wyodrębniany jest $\mathrm{w}$ biologii w odrębną naukę, równoleglą do ekologii, zwaną fizjologią środowiskową. Ta właśnie dziedzina jest najważniejsza dla oceny wpływu współczesnego środowiska na człowieka. Wpływ na strukturę populacji ludzkich miał szczególne znaczenie we wczesnych okresach antropogenezy. Powszechnie przyjmuje się, że kierunkowa selekcja naturalna nie ma miejsca we współczesnych populacjach ludzkich, bowiem oddziaływania kulturowe (medycyna, higiena, oświata), społeczne (opieka społeczna) i ekonomiczne (podnoszenie standardu życia) ograniczyły zachorowalność, umieralność i śmiertelność. W wyniku tego nie ma już miejsca 
dalsza ewolucja biologiczna człowieka. Selekcja jaka dzisiaj występuje działa jedynie $\mathrm{w}$ nikłym zakresie $\mathrm{w}$ okresie przed- $\mathrm{i}$ reprodukcyjnym na obu krawędziach rozkładu zmienności i ma znaczenie stabilizujące.

Powoduje to, że ekologia człowieka stała się naukową podstawą ochrony środowiska naturalnego, w szczególności kształtowania warunków życia człowieka. "Ochroniarze” i polityczne ruchy "zielonych" traktują sprawę ochrony środowiska emocjonalnie, zaś inżynierowie przyzwyczajeni są do dokładnych wyliczeń wszelkich działań. Stąd wynikają spięcia między działaczami zwącymi się „ekologicznymi” a planistami i inżynierami. Most porozumienia tworzy ekologia człowieka.

\section{Monitorowanie stanu biologicznego populacji}

Jedynym obiektywnym sposobem rejestracji wpływu środowiska (warunków życia, warunków bytowych) na człowieka jest ocena jego stanu biologicznego. Składa się na to: stan zdrowia (mierniki pozytywne i negatywne), stan odżywienia i sprawność reprodukcyjna (rozrodczość).

Zdrowie jest definiowane przez Światową Organizację Zdrowia (WHO) jako nie tylko brak chorób, ale pełnia dobrego samopoczucia psychofizycznego. Mierzymy go negatywnymi i pozytywnymi miernikami. Choroba to "chore zdrowie", jak się to obrazowo po angielsku (ill health) nazywa w epidemiologii. Występowanie chorób (częstość zachorowań) wchodzi w skład negatywnych mierników zdrowia. Mierzone są one wskaźnikami zachorowalności (nowe przypadki chorób), chorobowości (stare i nowe przypadki chorób) i śmiertelności (zgony z powodu konkretnych chorób). Jednak już wskaźniki umieralności są na pograniczu mierników negatywnych i pozytywnych, bowiem opisują czas trwania życia.

Choroba jest procesem, z punktu widzenia ekologii, narastających zaburzeń działania organizmu w danych warunkach środowiskowych. Stan poszczególnych chorych jest oceniany na podstawie ich samopoczucia (subiektywnie) lub na podstawie zmian patologicznych (organicznych) jakie choroba wywołuje $\mathrm{w}$ organizmie, a to zależy od czasu trwania i nasilenia choroby. Nie są to stany w pełni mierzalne i porównywalne - raczej zliczalne $w$ postaci ilości przypadków. Bardziej obiektywnymi miernikami są wskaźniki zwane pozytywnymi.

Zdrowie "pozytywne" jest mierzalne jako stan rozwoju fizycznego i sprawność psychofizyczna organizmu. Można je ocenić przy pomocy pomiarów morfologicznych (antropometrii), fizjologicznych, biochemicznych, testów sprawności psycho-motorycznej, wydolności roboczej itp. Dokonany pomiar porównuje się z normami skonstruowanymi na podstawie badań populacji (w gruncie rzeczy jej kohorty) w której nie 
stwierdzamy zmian patologicznych i obciążeń genetycznych. Populację taką nazywamy wzorcową. Aby ocena była wiarogodna porównania musimy dokonać względem populacji o podobnej częstości genów (puli genowej) jak ta z której wywodzi się oceniana osoba. Porównania dokonywane są także w skali całych populacji. Ocenianą populację, na podstawie miar tendencji centralnej i dyspersji, porównuje się z populacją wzorcową. Przy wyciąganiu wniosków należy uwzględnić fakt, czy podobne są ich pule genowe. O ile tak, można domniemać, że występujące różnice fenotypowe wynikają z wpływów środowiskowych. Dalsze analizy mogą doprowadzić do wyodrębnienia jak też określenia stopnia wpływu poszczególnych czynników środowiskowych.

Stan odżywienia dokonujemy poprzez pomiar komponentów (składników) ciała które odzwierciedlają zasoby (białkowe, tłuszczowe, mineralne) organizmu oraz zaopatrywanie w energię i witaminy. Są to dla przykładu wysycenie żelazem krwinek czerwonych $(\mathrm{Hb})$ i ich objętość względem surowicy (Hct), uwapnienie kości, zasoby tkanki tłuszczowej, stan rozwoju mięśni, stan skóry, uzębienia (szkliwa), itp.

Sprawność rozrodczą oceniamy poprzez płodność poszczególnych rodzin, oraz dożywanie do wieku rozrodczego. W ekologii człowieka ważne znaczenie ma tzw. zróżnicowana płodność i przeżywalność. O zróżnicowanej płodności mówią nam cechy kobiet często zachodzących w ciążę, lub czym cechują się pary małżeńskie które mają dużo potomstwa $\mathrm{w}$ porównaniu do tych które mają go mało.

O zróżnicowanej przeżywalności świadczą cechy osobników, którzy nie dożywają do okresu rozrodu. Istotne może się okazać także to czym charakteryzują się ludzie pozostający bezżennymi, a tym samym z własnego wyboru nie biorą udziału $\mathrm{w}$ reprodukcji i tworzeniu kolejnych pokoleń.

Ocena dobrobytu na podstawie samopoczucia psychicznego jest niedokładna, samopoczucie podlega emocjom, jest zmienne. Ocena taka na podstawie posiadanego majątku jest ułudna, bowiem jego wartość jest względna zależnie od tego jak jest wykorzystywany. Także ocena wartości społecznych: organizacji opieki zdrowotnej, pomocy społecznej, skuteczności komunikacji, rozwoju infrastruktur - jest trudna do przełożenia na dobro człowieka w postaci pełni jego zdrowia. Nie każdy człowiek ma równy do nich dostęp i predyspozycje ( $w$ tym psychiczne), aby z nich korzystać. $W$ dodatku wszystkie te "urządzenia" społeczne i techniczne mają swoje wady i zalety. Kształtowane przez ludzi środowisko zwrotnie wpływa na tychże i innych ludzi, modyfikując ich stan - nieraz w korzystnym, a nieraz $\mathrm{w}$ niekorzystnym kierunku - co właśnie można ocenić wskaźnikami stanu biologicznego.

Ocena kulturowego i społecznego sposobu przystosowania do środowiska nie jest miernikiem dobrostanu, jedynie pokazuje sposób w jaki dany człowiek czy społeczność walczy o przeżycie wobec warunków w jakich istnieje. 
W Indiach, gdzie wielu ludzi nie ma nic poza jakimś ubraniem, mieszka na kawałku chodnika pod płotem lub ścianą, zmierzenie stopnia ich nędzy jest praktycznie niemożliwe. Zamożność ocenić można poprzez stan konta $\mathrm{w}$ banku, posiadany dom, mieszkanie i jego wyposażenie, samochód, daczę itp. Ale jak zmierzyć bezmiar biedy? Także wśród bogatych, czy w warstwach średnich, nawet jeśli ludzie ci tyle samo pieniędzy wydają na żywność, to kupują inne produkty, inaczej je przyrządzają i inny jest skutek żywieniowy. Inny jest poziom higieny i zachowania zdrowotne. A więc nie tylko majątek, ale i praktyki kulturowe, status społeczny, wykształcenie wpływają na to jak żyjemy i co odczuwamy jako dobrostan.

Oceną stopnia ubóstwa może natomiast być uszczerbek na zdrowiu, mierzony stanem odżywienia organizmu, a raczej jego zabiedzenia oraz zahamowaniem procesów wzrastania i rozwoju fizycznego. Tak więc stan biologiczny pozostaje jedynym obiektywnym miernikiem dobrostanu człowieka. Stan biologiczny odzwierciedla warunki życia, a więc pośrednio stanowi miarę dobroci tak warunków przyrodniczych jak i społecznych oraz wartości zmian zachodzących w środowisku w jakim człowiek żyje. Stan biologiczny ocenia także zalety praktyk kulturowych, w tym zachowań prozdrowotnych, zabiegów higienicznych itp. Inne mierniki są względne, stan biologiczny jest "twardym faktem", zarejestrowanym w postaci zmian dokonujących się $\mathrm{w}$ organizmach konkretnych ludzi oraz w strukturze populacji. Można użyć zwrotu, że wszelkie zmiany środowiska, zmiany ustrojowe, kulturowe - pozostawiają ślady w biologii ludności. Powiązanie stanu biologicznego ludności ze społecznymi, ekonomicznymi i politycznymi warunkami w jakich żyje dana populacja jest jedną z ważnych dziedzin badań w ekologii człowieka, zarówno z punktu widzenia teoriopoznawczego, jak również w związku z wielką wagą społeczną takiego obiektywnego rozpoznania.

Bioekologia, nawet gdyby prowadziła badania populacji ludzkich, interesując się zmianami w strukturze populacji a nie indywidualnych organizmów (autekologią, fizjologią środowiskową), nie bada stanu zdrowia. Stąd jej znaczenie dla ochrony środowiska życia człowieka i jego dobrostanu, w tym zdrowia, jest znikome.

\section{Monitorowanie stanu środowiska, w tym warunków bytowych}

Gdy socjolog prowadzi badania instytucji społecznych na jakimś terytorium - jest to monitoring działań grupowych ludności je zamieszkującej. Gdy ekolog bada gatunki zasiedlające jakiś ekosystem - jest to monitoring tej biocenozy, jeszcze nie ekosystemu. Gdy etnolog bada zachowania kulturowe jakiejś grupy etnicznej - jest to monitoring jak się ona kul- 
turowo przystosowuje do środowiska. Gdy medyk czy antropolog (w USA zwany fizycznym) bada populacje ludzką z punktu widzenia zdrowia, rozwoju fizycznego lub stanu odżywienia i rozrodczości - jest to monitoring stanu biologicznego populacji ludzkiej. Tego typu badania sa tradycyjnie wykonywane $\mathrm{w}$ ramach odpowiednio socjologii, ekologii (a nawet jedynie zoologii czy botaniki), etnologii, epidemiologii czy biologii człowieka. Nie jest to, i nie ma potrzeby używać nazwy, ekologia człowieka. Każda z tych tradycyjnych dyscyplin naukowych opisuje (monitoruje) ze swego punktu widzenia człowieka lub środowisko. Sam opis - monitoring nie jest jeszcze nauką - odpowiada bowiem na pytanie co. Współczesna nauka odpowiada na pytanie jak lub dlaczego. W ramach poszczególnych dyscyplin takie pytanie bywa zadawane, i badane są interesujące $\mathrm{z}$ tego punktu widzenia zjawiska.

\section{Interakcja i modelowanie ekosystemów}

To wszystko o czym była mowa powyżej dotyczyło badań populacji i środowiska, jest to więc rejestracja stanu, ewentualnie także zmian $\mathrm{w}$ czasie. Nazywamy to $\mathrm{z}$ angielska monitorowaniem. Monitorowanie poszczególnych elementów ekosystemu nie wymaga ścisłej współpracy różnych specjalistów, natomiast pożądane jest aby badania wykonywane były na tym samym obszarze: charakterystykę geoklimatyczną obszaru, warunki biologiczne (faunę i florę) oraz zamieszkującą ten obszar populację ludzką. Na tym etapie ciągle nie ma konieczności współdziałania, ale bez zaplanowanej współpracy nie ma mowy o ekologii człowieka.

Metodą analizy i wnioskowania o mechanizmach owych interakcji zachodzących w ekosystemach, których częścią są populacje ludzkie, jest modelowanie. Modelowanie wymaga współpracy wymienionych poprzednio specjalistów oraz matematyków wyspecjalizowanych w programach modelowania. Ideałem jest aby byli to matematycy z wykształceniem również biologicznym.

Model pokazuje powiązania przyczyn i skutków. Wyjaśnia mechanizmy zmian $\mathrm{w}$ środowisku naturalnym, instytucjach społecznych i praktykach kulturowych, sposób korzystania ze środowiska i ich wpływ na stan biologiczny populacji. $W$ języku ekologii jest to badanie obiegu materii oraz przepływu energii i informacji przez ekosystem. $W$ trakcie tego obiegu zmieniają się elementy ekosystemu, jednym z takich elementów jest populacja ludzka, która jest związana ze środowiskiem biologicznie i kulturowo. Nisza człowieka, poza właściwymi dla wszystkich organizmów żywych powiązaniami biologicznymi wynikającymi z potrzeb organizmu, to także powiązania społeczne właściwe jedynie niektórym gatunkom, i powiązania kulturowe specyficzne jedynie dla człowieka. Kul- 
tura ludzka jest bardzo ważną częścią jego niszy. Właśnie powiązania kulturowe sprawiają, że modelowanie ludzkich społeczności jest znacznie bardziej skomplikowane, aniżeli ekosystemów w których nie ma miejsca działalność człowieka, lub też analiza ogranicza się do przepływu energii i obiegu materii, bez wnikania w przepływ informacji symbolicznej. W wyniku tego na ile modelowanie ekosystemów „naturalnych" w znacznym stopniu opanowano, modelowanie społeczności ludzkich znajduje się zaledwie na etapie próbnych analiz (np. Boyden i inni 1981).

Tak więc ekologia człowieka opiera się o dwie podstawy: stan populacji ludzkiej i stan środowiska w jakim ona żyje. Dla zrozumienia powiązań między tymi dwoma elementami, a więc zrozumienia zachodzących interakcji, konieczne jest poznanie nie tylko procesów biologicznych, ale także społecznych i kulturowych. Dopiero ta całość, ale nie każdy z elementów z osobna, stanowią ekologię człowieka. Jej podstawą teoretyczną jest więc teoria systemów, a metodą modelowanie.

Reasumując: istotą ekologii człowieka jest interakcja, a więc współdziałanie elementów systemu. Te elementy zostały zarejestrowane $\mathrm{w}$ procesie monitorowania. Celem ekologii człowieka jest odzwierciedlenie systemu w jaki owe elementy są ze sobą powiązane, czyli sporządzenie modelu powiązań. Ten model dotyczy systemu ekologicznego, w którego centrum znajduje się populacja ludzka. Taki etap nazywamy modelowaniem i jest on podstawą badań w zakresie zarówno bioekologii (wówczas gatunki badane są na tle środowiska $\mathrm{w}$ aspekcie przepływu energii i obiegu materii - np. jako sieć pokarmowa) jak i ekologii człowieka. W tej ostatniej dotyczy to zmian przystosowawczych populacji ludzkich do środowiska jako odzwierciedlenia jego stanu, oraz obiegu materii i przepływu energii przez systemy osadnicze i ekosystemy w których człowiek żyje, na które wpływa i które przez niego zmienione - wtórnie na niego oddziałują. Chodzi tu także o przepływ informacji zarówno w sensie genetycznym jak i kulturowych (symbolicznym).

\section{Powstanie i rozwój ekologii człowieka}

\section{(1) Monodyscyplinarna ekologia człowieka}

Termin ekologia człowieka pierwszy użył w 1916 roku Huntington wybitny geograf i podróżnik amerykański, chcąc zapobiec kryzysowi w geografii gdy doszła ona do kresu opisu ukształtowania powierzchni ziemi i jej przestrzennego zróżnicowania oraz rozmieszczenia ludności i artefaktów kulturowych. Wówczas właśnie Huntington wysunął koncepcję wyjaśniania istoty składu i ukształtowania powierzchni Ziemi i obiektów na niej występujących w postaci wzajemnych powiązań, a więc na tle otaczającego środowiska. Huntington wierzyl, że czynniki klimatyczne i ich wahania determinują możliwości ludzkie. Ludzie w każdym środowisku wybierają 
drogę mniejszego wysiłku, wydatku czy nakładu energii. Z tego punktu widzenia uważał sezonowe i terytorialne różnice temperatury i wilgotności, oprócz warunków ekstremalnych, za korzystne dla człowieka.

Podobny cel przyświecał chicagowskiej szkole socjologicznej pod kierunkiem Parka we wczesnych latach 1920-tych. Wzięte z biologii tło środowiskowe użyto jako pewną doktrynę socjologiczną głoszącą, że wspólnie zamieszkiwane terytorium (układ przestrzenny) jest środowiskiem scalającym społeczeństwo i wpływającym na charakter i strukturę związków społecznych. Te zaś mają podwójny charakter, zarówno biologiczny jak i kulturowy. Termin ekologia człowieka został użyty w dziele syntetyzującym owe poglądy w roku 1921. W dalszym rozwoju tej socjologicznej doktryny społeczeństwo rozumiano jako system samoregulujący się i ewoluujący. Przyjmowano, że ekologia człowieka jest „nauką o przestrzennych i czasowych stosunkach międzyludzkich w związku z wybiórczymi, różnicującymi i wymagającymi przystosowywania siłami środowiska". Według Parka biotyczne stosunki od współzawodnictwa o przestrzeń życiową po współdziałanie i symbiozę, dotyczą także człowieka. Kultura miałaby być superstrukturą nad biologiczną naturą społeczności ludzkich. Biologiczne mechanizmy współzawodnictwa, dominacji, inwazji i sukcesji miałyby mieć zastosowanie do organizacji i sposobu zachowywania się populacji ludzkich w miastach. Na tym tle powstała koncepcja stref koncentrycznych $\mathrm{w}$ terytorialnym układzie miast: najstarsze dominujące centrum biznesu jest otoczone przez obszary zasiedlone przez inne grupy społeczne, przejście do dzielnicy centralnej oznacza także awans społeczny. Z czasem jednak socjolodzy odeszli od koncepcji Parka, kwestionując uproszczone odniesienia mechanizmów biologicznych, opartych głównie o przesłanki ekonomiczne (gospodarki energetycznej), do populacji ludzkich. Współcześnie socjolodzy przyjmują, że w społeczeństwach miejskich nie występują proste biologiczno-ekonomiczne zależności, lecz złożone kompleksy uwarunkowań z dominacją zależności społeczno-kulturowych.

Kolejno ekologią człowieka nazwano dział medycyny zwany epidemiologią. W szczególności gdy mowa była o środowiskowych przyczynach chorób. W latach 1940-tych całość epidemiologii niektóre środowiska medyczne w Stanach Zjednoczonych zaczęły nazywać ekologią człowieka, co jednak nie spotkało się z powszechnym przyjęciem. Kierunek ten wywarł pewien pozytywny wpływ na epidemiologię, która była raczej ekologią chorób, a postuluje się aby była ekologią zdrowia, a więc chodzi o zwrócenie uwagi przede wszystkim na zapobieganie chorobom, umacnianie zdrowia, terapię traktując jako ostateczność. Powstaje więc problem zdrowotnych walorów środowiska.

Podobne monodyscyplinarne ujęcia istniały także w innych dziedzinach nauki; psychologii, etnologii, nawet archeologii. Nie wspomniano tutaj o antropologii, bowiem ona sama była od zarania przepełniona tre- 
ściami ekologii człowieka, od kiedy przyjęta została darwinowska teoria doboru naturalnego, która wyjaśniała powstanie i ewolucję człowieka siłami natury.

(2) Multidyscyplinarna ekologia człowieka

W roku 1964 powotany do życia zostat Międzynarodowy Program Biologiczny (IBP), a w nim zorganizowano sekcje adaptabilności człowieka (Human Adaptability - HA). Sekcja ta inicjowata $i$ koordynowata badania nad zmianami przystosowawczymi populacji ludzkich do zmieniajacych się warunków środowiska w różnych biocenozach i na różnym etapie rozwoju cywilizacyjnego. Ukierunkowane one byty na dwa główne tematy. Pierwszym z nich byt wptyw środowiska na (1) rozwój osobniczy, (2) organizm osobnika dorostego, (3) strukture chorobowości, (4) częstość genów (pule genowe populacji pierwotnych kultur). Drugim tematem byty badania adaptacji $i$ sposobu życia tradycyjnych populacji w ekstremalnych warunkach życia: zimnie, na dużych wysokościach w górach, w tropikach oraz na terenach suchych (pustynnych).

W ramach IBP nie zastosowano metody wspólnego areału badań, to jest rejestracji tego samego obszaru pod względem klimatu, zamieszkujących go gatunków roślin i zwierząt oraz populacji ludzkich. Dotyczyło to także sekcji HA. Badania poszczególnych właściwości prowadzono na ogół porównywalnymi metodami, ale obserwacje i pomiary (np. somatyczne, fizjologiczne, biochemiczne itd.) dokonywano nie na tych samych osobach, lecz na innych grupach czy nawet $w$ innych populacjach. Nie można więc było badać związków przyczynowych, z nawet współwystępowania. Była to mozaika wiedzy, którą trudno było zsyntetyzować. W wyniku tego nie doprowadzono do ujęć międzydyscyplinarnych. Okres trwający od roku 1964 przez kolejnych 20 lat w EC nazywamy multidyscyplinarnym.

Definicję ekologii człowieka jako „naukę o człowieku i jego środowisku" odrzucono w latach 1970-tych. Wyliczono bowiem, że tak określony zakres obejmuje ponad $70 \%$ ludzkiej wiedzy, a więc jest to wiedza nieomal o wszystkim. W nauce, a przynajmniej w naukach eksperymentalnych (czy opartych o obserwowane eksperymenty naturalne), nie oznacza to nic. Jest to przedmiot filozoficznych spekulacji.

Ekologia człowieka w części środowiskowej jest nauką eksperymentalną, w części dotyczącej populacji ludzkich monitoruje jedynie dokonujące się zmiany w ludzkich organizmach i populacjach (obserwacja tzw. eksperymentu naturalnego).

(3) Początki systemowej ekologii człowieka

Okres multidyscyplinarny stanowił mozaikę wiedzy, trzeba było następnych co najmniej dwudziestu lat, aby ukształtowały się systemowe ujęcia, głównie pod wpływem powstałej w 1985 roku International Commission of Human Ecology. 
W 1985 roku Prezydium IUAES zwróciło się do N. Wolańskiego o zorganizowanie komisji ekologii człowieka, jako dziedziny interdyscyplinarnej - stanowiącej powiązanie między naukami biomedycznymi i społeczno-kulturowymi. W ramach tej komisji wypracowana została koncepcja systemowej transdyscyplinarnej ekologii człowieka

Od tego okresu wraz z powołaniem Komisji Ekologii Człowieka (CHE) przez Międzynarodową Unię Nauk Antropologicznych i Etnologicznych (IUAES) kształtuje się w zinstytucjonalizowanej postaci współczesna ekologia człowieka. Komisja poprzez International Social Science Council jest afiliowana przy UNESCO. Początki organizacji $\mathrm{w}$ tym kierunku datują się około 10 lat wcześniej w postaci Komisji "Człowiek i Środowisko" tejże Unii, lecz było to ujęcie zbyt szerokie (obejmowało także problemy ochrony środowiska) i ten zakres został zarzucony, a Komisja zlikwidowana. Koncepcyjnie systemowe ujęcie transdyscyplinarne reprezentował już od końca lat 70-tych przede wszystkim amerykański ekolog Gerald L. Young (członek CHE), aktualnie redaktor naczelny Journal of Human Ecology. Teoretyczną prezentację ekologii człowieka przedstawił on w swej monografii w 1989 roku. Polska miała chronologicznie pierwszą z nazwy placówkę naukową w zakresie ekologii człowieka w skali światowej. Była to organizowana w latach 1958-60, a oficjalnie powołana w roku $1961 \mathrm{w}$ ramach Zakładu Morfofizjologii Rozwoju, Instytutu Matki i Dziecka - Pracownia Ekologii Dziecka, w roku 1969 przeniesiona do Polskiej Akademii Nauk pod nazwą Zakładu Ekologii Człowieka. Placówka ta od początku prowadziła kompleksowe badania (początkowo około 600) morfologicznych, fizjologicznych i psychomotorycznych cech na tych samych osobach z różnych regionów Polski, porównując stan biologiczny mieszkańców miast, wsi i terenów uprzemysłowionych wraz $\mathrm{z}$ ich przemianami. $\mathrm{W}$ badaniach tych dość dokładnie udokumentowane były lokalne warunki klimatyczne i przyrodnicze, oraz warunki życiowe badanych rodzin, w tym sposób żywienia się oraz rozrodczość. Zarówno więc stan biologiczny populacji ludzkich jak i warunków środowiskowych był dobrze udokumentowany. Był to jeden $\mathrm{w}$ pierwszych na świecie monitoring populacji i tych konkretnych warunków w jakich w danym czasie dana populacja żyła.

Działo się to już wówczas gdy dopiero organizowany był program IBP i w czasie spotkania organizatorów sekcji adaptabilności człowieka, gdy inne kraje przedstawiały dopiero programy badań, ze strony polskiej placówki wiosną 1965 roku w University Park w USA zaprezentowane zostały wyniki owych kompleksowych badań. W latach 1975-78 zorganizowano w Polsce serię międzynarodowych warsztatów (zwanych wówczas kursokonferencjami) z zakresu ekologii człowieka w Centrum Konferencyjnym PAN w Jabłonnie. W roku 1990 opublikowany został pod szyldem Komisji Ekologii Człowieka IUAES finansowany przez UNESCO pierwszy słownik terminów z zakresu ekologii człowieka (Wolański 1990), w roku 1996 
wydano bibliografię ze streszczeniami (tzw. adnotowaną - Siniarska i Dickinson 1996) oraz sponsorowano wydanie książek zbiorowych „Rodzina jako środowisko rozwoju człowieka” (Wolański i Bogin 1995) i „Ekologia starzenia" (Siniarska i Wolański 2000). Komisja w latach 1986-2003 zorganizowała osiem Światowych Konferencji Ekologii Człowieka (WACHE) w Hiszpanii, Jugosławii, Polsce, Meksyku, Australii, USA, Chinach i we Włoszech oraz jedno sympozjum międzydyscyplinarne w Afryce Południowej.

Od końca lat 50-tych P. Baker w USA zaczął prowadzić wykłady z ekologii człowieka (Baker 1996), w tym samym czasie N. Wolański zorganizował zakład ekologii człowieka w Polsce (Górnicki 1963). Wówczas ci dwaj ludzie nie znali się wzajemnie, i żyjąc w odrębnych systemach politycznych, o sobie nie słyszeli, obieg czasopism był bowiem utrudniony. Potem spotkali się i działali razem od roku 1964 w IBP. Wolański miał wówczas 35, Baker 37 lat. Ekologia człowieka jako multidyscplinarna nauka narodziła się w sekcji human adaptability IBP.

Można domniemać, że istnieje pewna konwergencja toku myślenia, dojrzewania do pewnych sformułowań czy podsumowań u ludzi zajmujących się podobną problematyką $\mathrm{w}$ różnych krajach. Konwergencja taka znana jest dla kultur starożytności, cywilizacja Egiptu oraz Olmeków i Majów powstała niezależnie od siebie, i podobne były ich odkrycia dotyczące astronomii i czasu, ale jedni wynaleźli koło, drudzy pojęcie zera $\mathrm{w}$ matematyce, są więc i różnice. Wielokrotnie się nad czymś zastanawiamy i po pewnym czasie podobne myśli znajdujemy w gazetach.

\section{Cztery działy ekologii człowieka}

Współcześnie ekologia człowieka w poszczególnych ośrodkach akademickich na świecie jest różnie definiowana i różnie jest określany jej zakres. Do dzisiaj istnieją studia typu monodyscyplinarnego, multidyscyplinarnego i bardzo niewiele systemowych - transdyscyplinarnych. Jednak istnieje tendencja do rozwijania we współczesnej ekologii człowieka nurtu transdyscyplinarnego w ujęciu systemowym. Chodzi tu o to, że związki osoby i populacji ludzkich ze środowiskiem rozpatrywane są jako synteza różnych dziedzin wiedzy - biologii, geografii, antropologii, etnologii, socjologii - a więc $w$ ujęciu interdyscyplinarnym. $Z$ drugiej strony stosowana jest tu analiza wzajemnych powiązań zjawisk - a więc ujęcie prezentowane przez teorię systemów. W tak rozumianej ekologii człowieka są wyróżniane 4 działy: (1) filozoficzne problemy relacji człowieka (ludzkości) ze środowiskiem, (2) przyrodnicze i społeczno-ekonomiczne problemy środowiska człowieka, (3) środowiskowe (ekologiczne) problemy biologii człowieka oraz (4) kulturowe zachowania przystosowawcze, ze szczególnym uwzględnieniem wychowania "do środowiska" (ryc. 1). 


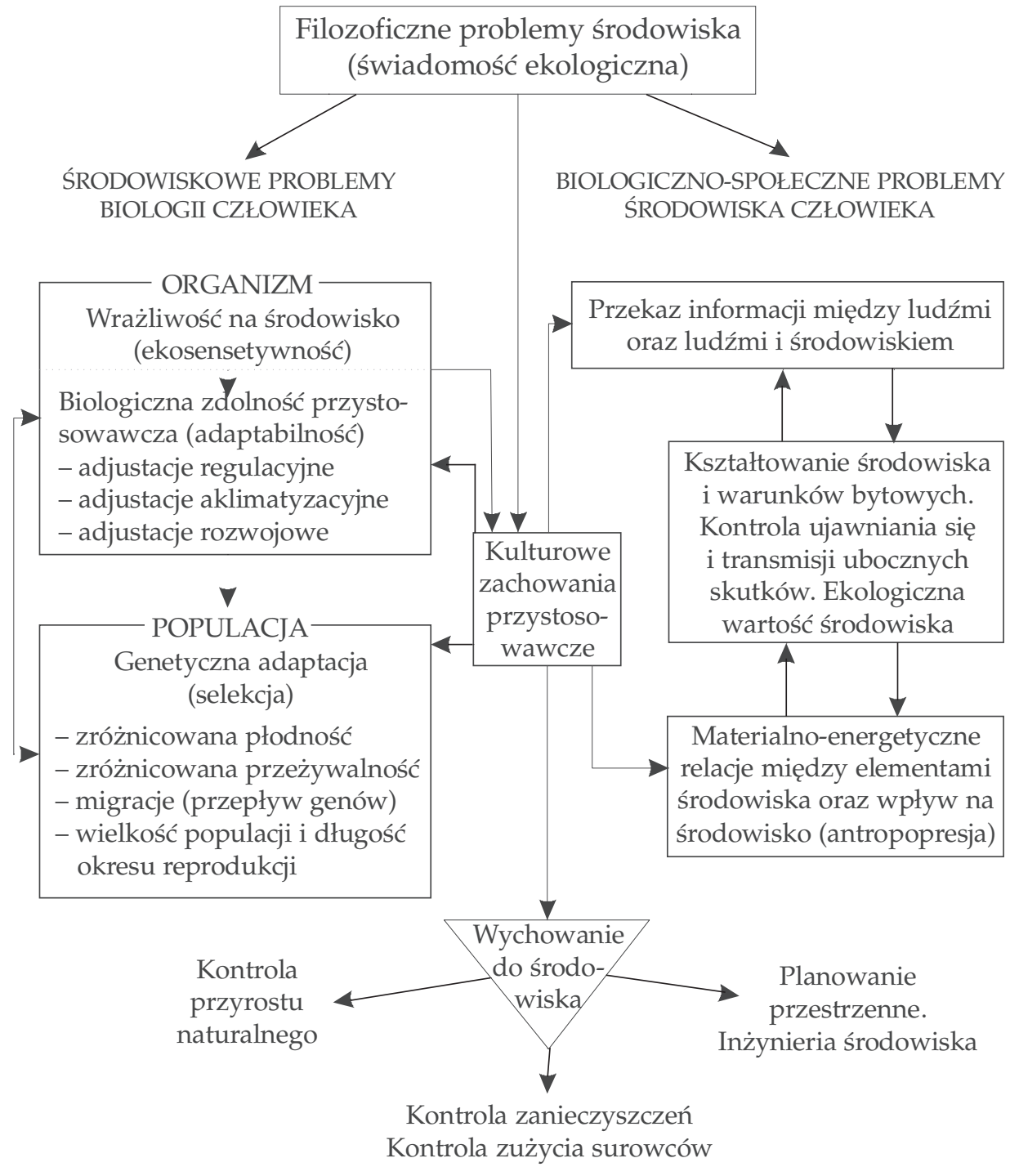

Ryc. 1. Cztery działy ekologii człowieka

Nie są to jednak działy samodzielne, jako takie należą do oddzielnych dyscyplin. Ich łączne ujęcie, a w szczególności rozpatrywanie związków między stanem biologicznym człowieka a warunkami środowiskowymi, odbiorem środowiska przez człowieka, zwrotnym oddziaływaniem antropopresji na populacje ludzkie - stanowią dopiero o istocie transdyscyplinarnej systemowej ekologii człowieka. 
(1) Filozoficzne problemy relacji człowieka (ludzkości) ze środowiskiem

Problemy relacji człowieka ze środowiskiem od zarania ludzkości były przedmiotem licznych refleksji. Ścierały się tu dwa poglądy, jeden o determinującej (fatalistycznej), a drugi o twórczej (kreatywnej) roli przyrody, w życiu ludzkości. Wiązały się one z odbiorem (odczuwaniem) przyrody oraz związanych z tym wierzeń i postaw. Poglądy te dotyczyły zależności naszego istnienia od przyrody jako żywicielki, próby zrozumienia działania sił przyrody, możliwości wykorzystania przyrody dla dobra człowieka, wreszcie problemów dewastacji przyrody przez cywilizację miejsko-przemysłową (problemy antropopresji). Na tym tle powstało szereg problemów filozoficznych, a w ostatnich czasach także etycznych. Ukształtowana obecnie nowa dziedzina nauki zwana bioety$\mathrm{ka}, \mathrm{w}$ wielu aspektach wkracza w problemy relacji człowieka ze środowiskiem. Ważnym problemem jest tzw. świadomość ekologiczna społeczeństwa. Ten dział filozofii przyrody $\mathrm{w}$ połączeniu $\mathrm{z}$ emocjonalnymi wpływami natury na psychikę i biologię człowieka - stanowi przedmiot zainteresowań ekologii człowieka.

(2) Przyrodnicze i społeczno-ekonomiczne problemy środowiska człowieka,

Przyrodnicze, społeczne, ekonomiczne i polityczne problemy środowiska człowieka są przedmiotem badań wielu dziedzin nauki. Przede wszystkim chodzi o zasoby środowiskowe i sposób ich eksploatacji. Ekologia człowieka odgrywa tu rolę syntetyzującą dla potrzeb praktyki. Badania dotyczą przepływu informacji między ludźmi oraz nimi i środowiskiem; przepływu energii przez ekosystemy w związku z presją człowieka na środowisko; wreszcie tworzenia i przekształcania warunków środowiska życia populacji ludzkich, kontroli ubocznych skutków przekształceń środowiska, i oceny zdrowotnych wartości środowiska. Te ostatnie nie mogą być dokonane bez badania stanu biologicznego populacji ludzkich. Dział ten syntetyzuje wiedzę ekologiczną dotyczącą działania ekosystemów z uwzględnieniem w nich roli populacji i społeczności ludzkich. Wiąże się to z ekologią krajobrazu. Ważnymi społecznie zagadnieniami są problemy kształtowania środowiska i warunków bytowych, kontrola ujawniania się i transmisji ubocznych skutków cywilizacji miejsko-przemysłowej, wreszcie problemy ekologicznej wartości środowiska. Chodzi tu zarówno o rejestrowanie stanu biocenoz jak analizę przepływu materii, energii i informacji w ekosystemach oraz rolę społeczności ludzkich. Jest to dział nawiązujący do geologii, geografii, ekologii, ekonomii. Ocena zmian jest jednak dokonywana przez odniesienie wpływu na populacje ludzkie.

(3) Środowiskowe (ekologiczne) problemy biologii człowieka

Środowiskowe problemy biologii człowieka - stanowią centralny obszar ekologii człowieka, jako transdyscyplinarnej nauki. Dział ten opiera 
się na naukach biomedycznych. Zajmuje się mechanizmami dostosowywania się organizmów do środowiska (adjustacjami) i genetycznymi przystosowaniami (adaptacjami) populacji ludzkich do warunków danych ekosystemów, w szczególności silnie modyfikowanych przez cywilizację miejsko-przemysłową. Bada więc zjawiska wrażliwości organizmu na bodźce środowiskowe (ekosensytywności), oraz morfofizjologicznych i psychicznych zdolności przystosowawczych (adaptabilności). Analizuje granice tolerancji organizmu zależnie od jego genetycznych właściwości, sposobu żywienia i trybu życia. Opisuje zjawiska dostosowania (adjustacji) organizmu do aktualnych warunków środowiskowych (fizjologia środowiskowa). Bada przystosowawcze zmiany puli genowej populacji na drodze zróżnicowanej płodności i przeżywalności, oraz przemiany zachodzące między pokoleniami w związku z przyrodniczymi i społeczno-ekonomicznymi zmianami warunków życia. To ostatnie wiąże się ze zjawiskami z pogranicza demografii i genetyki populacyjnej $\mathrm{w}$ sensie selektywnego przepływu genów. Poważnym problemem związanym z praktyką jest tu rejestracja stanu biologicznego organizmu i struktury populacji (także w sensie puli genowej), na tle wpływu na ten stan czynników środowiskowych. Dział ten nawiązuje do antropologii (biologicznej), fizjologii, immunologii, genetyki, epidemiologii, bromatologii.

\section{(4) Kulturowe zachowania przystosowawcze, ze szczególnym uwzględnieniem wychowania "do środowiska"}

Kulturowe zachowania przystosowawcze, ze szczególnym uwzględnieniem wychowania "do środowiska". [Termin ten jest kontrowersyjny, pochodzi z angielskiego education for environment. Jednak wychowanie "dla środowiska", także nie oddaje istoty rzeczy. Inną wersją może być edukacja środowiskowa, co jednak oddaje raczej aspekt kształcenia aniżeli wychowania]. Po pierwsze mieszczą się tu zachowania społeczno-kulturowe jako mechanizmy przystosowawcze, osłaniające konieczność zmian biologicznych organizmu człowieka i struktury populacji ludzkich. Modernizacje i nowoczesność są tu rozumiane jako sprawność w przystosowaniu do środowiska. W tym dziale mieści się oparte na przesłankach filozoficznych i etycznych wychowanie społeczeństwa do współżycia z przyrodą poprzez stałe z nią kontakty i do szanowania naturalnego środowiska naszego życia. Cel ten ma być osiągnięty poprzez kształtowanie tzw. świadomości ekologicznej. Dział ten nawiązuje do psychologii, socjologii, archeologii, etnologii, politologii, ekonomii. Z działu tego wynikają także pewne wskazówki dotyczące kontroli przyrostu naturalnego, planowania przestrzennego i urbanistyki, inżynierii środowiskowej oraz kontroli zanieczyszczeń i zużycia surowców nieodnawialnych. Przesłanki stąd wynikające mają zastosowanie $z$ jednej strony do sozologii (nauki o ochronie środowiska i zasobów przyrody), z drugiej do pedagogiki. 
Już z powyższych sformułowań wynika, że w ekologii człowieka zawsze istniały dwie nierozłączne strony każdego zjawiska: populacje ludzkie i środowisko ich życia. Istotą ekologii człowieka jest kompleksowe (systemowe) badanie współzależności między człowiekiem i jego środowiskiem. O ile badamy jedynie środowisko nie jest to ekologia człowieka, lecz geologia, geografia czy biologia - w sensie przyrodniczym, lub ekonomia, socjologia czy etnografia - $\mathrm{w}$ sensie kulturowym. $\mathrm{O}$ ile badamy jedynie człowieka, nawet ze środowiskiem $\mathrm{w}$ tle, nie będzie to ekologia człowieka, lecz anatomia czy fizjologia osobników gatunku Homo sapiens, antropologia, lub genetyka populacyjna czy demografia grup ludzkich.

\section{Niektóre współczesne problemy badawcze}

Do ważniejszych współczesnych kierunków badań należą: (1) problemy energetyki w aspekcie strategii przeżycia i rozrodu, (2) ewolucja proporcji zmienności fenotypowej do genetycznej, (3) zjawiska przejść demograficznych i epidemiologicznych, (4) problemy zanieczyszczeń środowiskowych i wpływu na zdrowie człowieka, (5) sprawa przemian warunków bytowych i antagonizmów miasto-wieś oraz między warstwami społecznymi, (6) ewolucyjne i behawioralne problemy ekologii człowieka. Wszystkie one, obok znaczenia teoriopoznawczego, bezpośrednio lub pośrednio związane są z przystosowaniem człowieka do środowiska oraz ochroną środowiska życia człowieka.

(1) Problemy energetyki w aspekcie strategii przeżycia i rozrodu

Sposób przeżycia zależy od warunków w jakich dane organizmy się znajdują. W środowisku niestabilnym żyje wiele organizmów, ale większość $\mathrm{z}$ nich ginie przed osiągnięciem zdolności do rozrodu wobec trudności pozyskania pokarmu i utrzymania równowagi ze zbyt zmiennym środowiskiem. W tej sytuacji poszczególny organizm nie ma szansy przystosować się jako jednostka, następuje to na poziomie populacji - ulegają eliminacji takie organizmy, które nie są zdolne do pozyskania żywności wobec zbyt dużej ich liczby względem pojemności środowiska. Przeżywają osobniki nieliczne, zdolne do przeżycia, które wygrały w tej konkurencji. Siłą sprawczą tego zjawiska jest dobór naturalny. Sposób przeżywania poprzez przystosowanie na poziomie populacji nazywamy strategiq $r$ (rozrodu masowego). Strategia ta występuje wśród mniej skomplikowanych organizmów, których energetyczny koszt reprodukcji nie jest wysoki na jeden organizm potomny.

W środowisku stabilnym żyje ograniczona liczba osobników, taka jaka wynika z pojemności środowiska, to jest dla jakiej istnieją warunki 
wyżywienia się oraz inne warunki konieczne dla życia. Osobnicy ci są więksi, wolniej wzrastają i są bardziej niezależni, od niewielkich zresztą, wahań warunków środowiskowych. W tej sytuacji inwestycja energetyczna w potomstwo okazuje się korzystna, wobec niskiej szansy utraty potomstwa lepiej przygotowanego do życia i rozrodu $\mathrm{w}$ stabilnych $\mathrm{i}$ przewidywalnych warunkach. Ten sposób przeżywania poprzez dopasowanie organizmu do warunków i pojemności środowiska zachodzi więc na poziomie organizmu i nazywamy go strategia K (zgodności z pojemnością środowiska). Strategia ta jest typowa dla dużych organizmów o skomplikowanej budowie i czynnościach organizmu, których rozwój jest kosztowny energetycznie, stanowi więc poważną inwestycję - która wobec dużej selekcji nie byłaby opłacalna.

Poszczególne gatunki w procesie ewolucji dostosowały się do jednej z tych strategii aby przeżyć. Wybór strategii prowadził do zmian filogenetycznych gatunków. Pewne analogie do wspomnianych strategii można także odnieść do różnic występujących między współczesnymi populacjami tego samego gatunku, także i populacji ludzkich.

Konkurencja o źródła energii, oraz zwiększone spożycie łatwiej przyswajalnego białka zwierzęcego, doprowadziła do przekształceń ewolucyjnych Hominidów w zakresie rozwoju poszczególnych tkanek: ograniczenia masy trzewi, a rozwoju tkanki nerwowej, w szczególności ośrodkowego układu nerwowego (Aiello i Wells 2002).

W znacznie mniejszej skali, podobna strategia występuje we współczesnych ludzkich populacjach. W populacjach biednych małżonkowie mają dużą liczbę dzieci, z których jedynie nieliczne dożywają do okresu rozrodu (np. populacje z Indii). Wśród populacji, które więcej inwestują w rozwój potomstwa, lepiej je żywią i kształcą większość potomstwa dożywa nie tylko do okresu rozrodu, lecz nawet do starości (przypadek współczesnych populacji europejskich oraz ich potomków w USA). W populacjach, które silnie się rozmnażają, dzieci są małe, nie tracą więc energii na wzrastanie. Te, które przyjmują strategię wzrastania wielkości ciała, mniej się reprodukują.

Realizacja strategii K, inwestycji w postaci dobrze do życia przygotowanego potomka, wymaga nakładów i jest możliwa w konkretnych warunkach środowiskowych. Kiedyś strategia ta w populacjach ludzkich prowadziła do zmian biologicznych, a więc ona pokierowała filogenezą człowieka. Z tego okresu pochodzą przystosowania organizmu do odmiennych warunków klimatycznych, zdecydowała o tym selekcja kierunkowa. Selekcja inaczej dobierała osobników pod względem wielkości, powierzchni i masy ciała, bowiem każda z tych właściwości ma nieco inne znaczenie dla przeżycia $\mathrm{w}$ poszczególnych warunkach klimatycznych. Produkcja ciepła jest proporcjonalna do masy ciała, natomiast powierzchnia do utrata ciepła. U ludzi mniejszych większa powierzchnia przypada 
na $1 \mathrm{~kg}$ masy ciała, aniżeli u ludzi o dużych wymiarach, osobnik mniejszy łatwiej więc traci nadmiar ciepła, a dużemu łatwiej jest takiej utracie zapobiec. Niektóre cechy są bardzo ważne dla możliwości rozrodu, jest nią na przykład masa ciała płodu czy wielkość głowy. Dobór naturalny masy urodzeniowej $\mathrm{u}$ współczesnego człowieka ma charakter wybitnie stabilizujący, umieralność jest tym wyższa im noworodek bardziej odchyla się od przeciętnej masy urodzeniowej. Co jednak istotne, jest to nie tyle selekcja ze względu na wielkość ciała jako taką, ale wielkość jest zwykle związana z pewnymi zaburzeniami w budowie ciała, nie rzadko współwystępuje z wadami czy zaburzeniami genetycznymi.

Strategia przeżycia decyduje zarówno o działaniu organizmu jak i tempie jego rozwoju. Poziom hormonów i czynników wzrostu jest pochodną poziomu cukru we krwi, a z drugiej strony w ciągu całego życia hormony wzrostu wpływają na poziom metabolizmu. Skutki niedożywienia, chorób i zaburzeń emocjonalnych hamują procesy wzrastania, ale zazwyczaj są wyrównywane (zjawisko doganiania - catch-up). Powolne wzrastanie i niska wysokość ciała są wyrazem przystosowania do środowiska. Przy znacznym niedożywieniu umieralność jest większa wśród szybko rosnących i dużych jak na swój wiek dzieci. W procesie ontogenezy wraz ze zmniejszaniem się tempa rozwoju, już od niemowlęctwa zmniejsza się umieralność.

W czasie ewolucji człowieka miało miejsce zwiększanie się masy noworodków, co obniżało stosunek masy ciała przypadającej na jednostkę powierzchni i zapobiegało utracie ciepła. Jednocześnie następował wzrost mającej izolujące znaczenie podskórnej tkanki tłuszczowej, wzrastała ilość brunatnej tkanki tłuszczowej, będącej magazynem energii, występowała aktywna termoregulacja $\mathrm{w}$ czasie snu, oraz wypracowanie gospodarki energetycznej już w czasie wczesnego niemowlęctwa. Miało to miejsce przypuszczalnie już na etapie Homo erectus lub wcześniej, w związku z nieowłosionym ciałem tych form ludzkich, spaniem na ziemi przy chłodnych nocach i wysoką umieralnością niemowląt. Przeżywały więc te osobniki, które charakteryzowały się wspomnianą oszczędną gospodarką energetyczną (Pawłowski 1998, 1999). Owo gromadzenie się podskórnej tkanki tłuszczowej tłumaczy też, nie mające miejsca u innych ssaków, stałe występowanie powiększonych sutek kobiet do postaci biustu.

Strategia przeżycia została też inaczej ukształtowana w poszczególnych okresach rozwoju osobniczego. Zabezpieczenia immunologiczne $u$ małego dziecka są dwukrotnie silniejsze niż u dorosłego, co chroni je w czasie tego trudnego do przeżycia okresu. Z kolei powolny rozwój układu rozrodczego oznacza także oszczędność energetyczną. Pierwszym skutkiem aktywności hormonów płciowych jest stymulacja skoku pokwitaniowego, potem zwiększenie poziomu tych samych hormonów powoduje zamknięcie tarcz wzrostowych i zakończenie wzrastania. 
Z gospodarką energetyczną związane są zmiany tempa rozwoju osobniczego. Dotyczy to powstania u gatunku Homo sapiens okresu dzieciństwa (od zakończenia karmienia piersią do wyrżnięcia się pierwszych zębów stałych), w którym ma miejsce zwolnione wzrastanie (Bogin 1999).

Zróżnicowane jest także tempo rozwoju w okresie pokwitania zależnie od warunków bytowych. W populacjach niedożywionych następuje przedłużenie tzw. skoku pokwitaniowego. W czasie zwiększonej sekrecji gonad (gonadarche) ma miejsce przyspieszenie procesów wzrastania, które powoduje między innymi przyrost wysokości ciała o około 20-25 $\mathrm{cm}$. W populacjach niedożywionych trwa to 3-5 lat i maksymalny przyrost roczny wynosi ok. 6-8 cm, w populacjach dobrze żywionych skok pokwitaniowy trwa 2-3 lata, a maksymalny przyrost roczny u poszczególnych osób wynosi 10 do 14 cm. (Siniarska i Zielińska 2002).

Współcześnie modele powyższych strategii służą do analizy stanu biologicznego populacji żyjących w różnych warunkach społecznych, ekonomicznych i w różnych systemach politycznych.

(2)Udział zmienności fenotypowej do genetycznej w filogenezie człowieka

Zmienność genetyczna rodzaju Homo co najmniej pod względem wielkości ciała i pojemności mózgu wykazuje w ciągu ostatnich stu tysięcy lat jedynie pewne fluktuacje. Jednak co najmniej od okresu neolitu zmienność międzypopulacyjna ulega zmniejszeniu, przypuszczalnie $\mathrm{w}$ związku z unifikacją warunków życia $\mathrm{w}$ osiadłych populacjach rolniczych, które używają bardziej podobnych metod produkcji żywności, aniżeli miało to miejsce dla izolowanych grup łowców-zbieraczy. W tym czasie, szczególnie od okresu średniowiecza ulega jednak zwiększeniu zróżnicowanie wewnątrzpopulacyjne, przypuszczalnie w związku ze stratyfikacją społeczno-ekonomiczną. We współczesnych populacjach zmienność fenotypowa $w$ ubogich warstwach społecznych jest wyższa, aniżeli $\mathrm{w}$ warstwach zamożnych, w których zaspokojone są podstawowe potrzeby życiowe. Także $\mathrm{w}$ trakcie rozwoju osobniczego następuje zmniejszanie się zmienności fenotypowej, co obserwujemy już w okresie niemowlęcym. Zjawisko to związane jest $\mathrm{z}$ unifikacją charakteru opieki rodzicielskiej i warunków bytowych. Zmienność narasta ponownie w okresie pokwitania na skutek kontrolowanej genetycznie aktywności neurohormonalnej, lecz po tym okresie ponownie ulega zmniejszeniu. W opisanej sytuacji względnie stabilnego zróżnicowania genetycznego, a zmniejszonej zmienności fenotypowej (ryc. 2), narasta pokusa manipulowania możliwościami adaptacyjnymi człowieka. Jest to ważny problem badawczy oraz dylemat etyczny na ile wolno nam stosować większe obciążenia organizmu $\mathrm{w}$ warunkach urbanizacji i industrializacji, a w jakim stopniu konieczna jest ochrona środowiska życia $\mathrm{w}$ jakim człowiek powstał i ewoluował (Wolański i Siniarska 2002), 


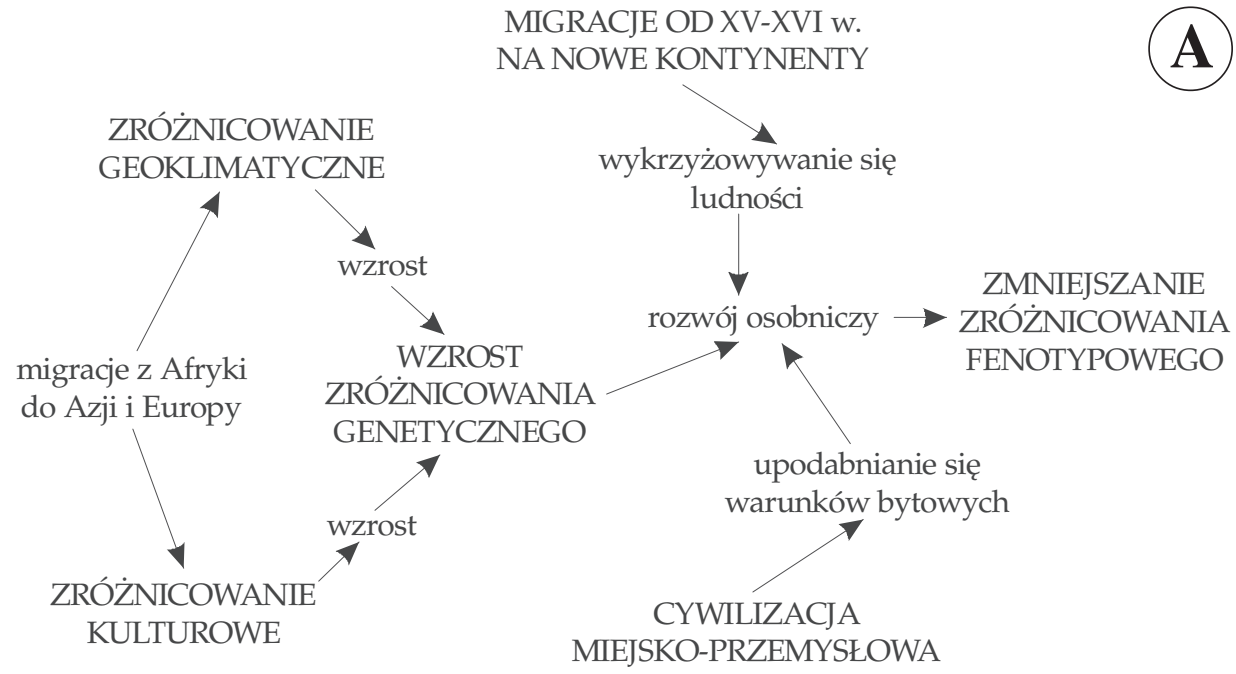

Ryc. 2. Model I (A): migracja ludności z Afryki południowej i wschodniej około 100.000 lat temu na inne tereny Afryki oraz Azji i Europy i wpływ zróżnicowanego środowiska w jakich się populacje te osiedliły na wzrost zróżnicowania genetycznego i kulturowego. W drugiej fazie od czasu wielkich odkryć geograficznych następują wtórne migracje, w szczególności z Europy, a następnie z Afryki (niewolnicy) na teren Ameryk, co skutkowało powstawaniem krzyżówek międzyodmianowych. W trzeciej fazie rozwój techniki, cywilizacji miejskiej a następnie przemysłowej prowadziły do upodabniania się warunków bytowych w skali światowej, to z kolei prowadziło do zmniejszania się różnic fenotypowych między populacjami.

(3) Zjawiska przejść demograficznych i epidemiologicznych

$\mathrm{W}$ zjawiskach przyrostu naturalnego oraz relacji organizmu do środowiska występują w historii ludzkości pewne istotne przemiany.

W demografii mamy do czynienia z tzw. przejściami demograficznymi, które charakteryzują się zmianą proporcji zgonów do urodzeń. Wyróżnia się zazwyczaj pięć etapów przemian demograficznych. Podział ten opiera się o analizę ruchów naturalnych ludności. Wyróżniane są następujące etapy: I - populacja stacjonarna o zrównoważonej wysokiej rozrodczości i umieralności, II - wczesny wzrost populacji (nadal wysoka rozrodczość, obniża się umieralność), III - późny wzrost populacji (obniża się zarówno rozrodczość jak i umieralność), IV - populacja stacjonarna o zrównoważonej niskiej rozrodczości i umieralności, V - populacja zmniejszająca się (o niskiej umieralności i jeszcze niższej płodności). Między etapem I a II, wraz ze wzrostem przyrostu naturalnego ludności, rozpoczyna się przejście demograficzne, a osiąga ono kulminację w momencie szczytowego przyrostu, a więc między etapem II i III. Przejście wygasa stopniowo między etapem III i V wraz ze spadkiem przyrostu naturalnego. W Polsce mamy do czynienia ze znacznymi przekształceniami demograficznymi w ciągu XX wieku, których skutki są nadal odczuwalne. Przejście demograficzne w Polsce miało miejsce w latach 1953-55. 


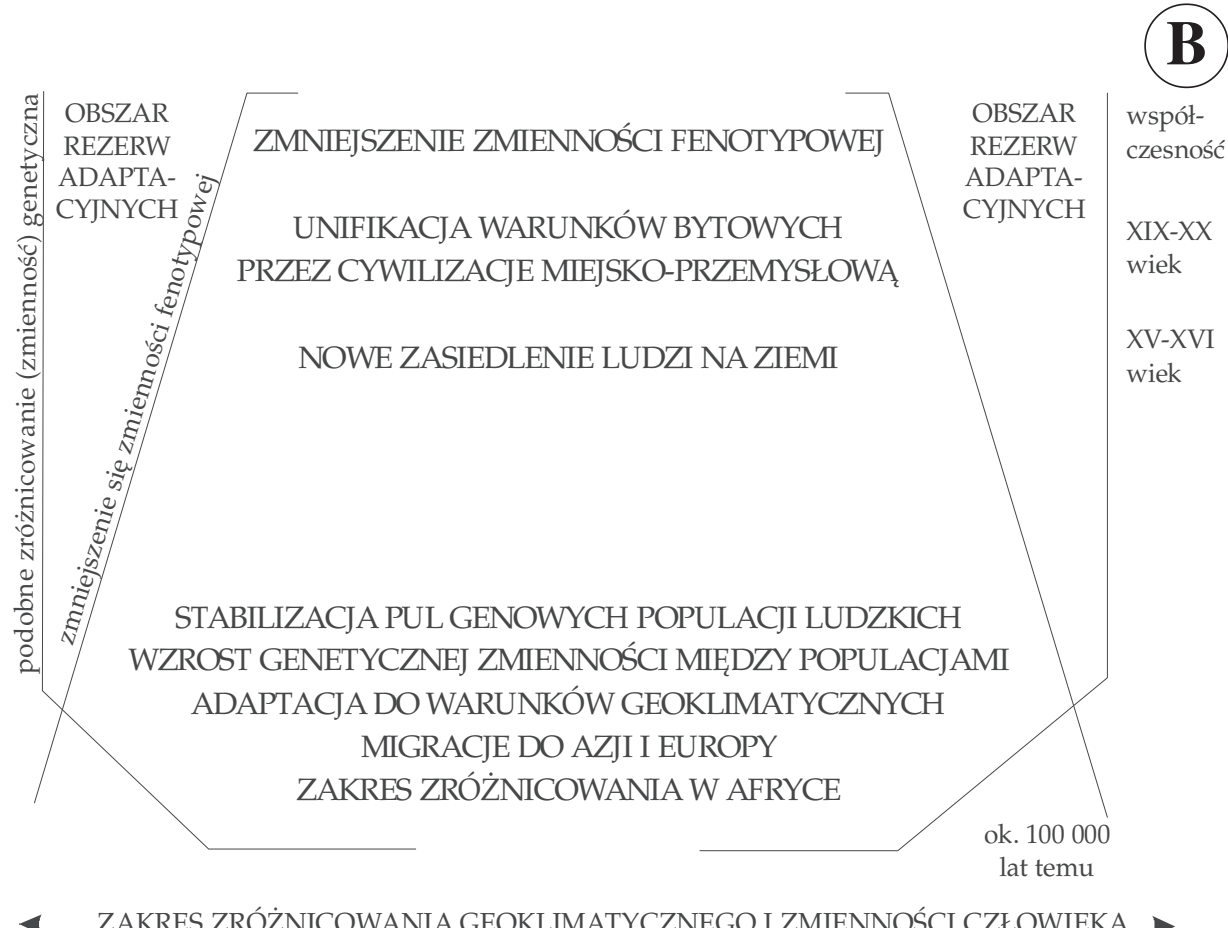

Ryc. 2. Model II (B): W ciągu ostatnich kilkudziesięciu tysięcy lat względnie stabilna jest zmienność genetyczna ludzkości, wobec ochrony jaką stwarza system kulturowy. Co najmniej od powstania stałych osad rolników w okresie neolitu, wraz z rozwojem pierwszych cywilizacji, nastąpiło upodobnienie się warunków bytowych między populacjami. Prowadzi to do zmniejszania się zmienności fenotypowej ale i zarazem do powstawania rezerw adaptacyjnych.

Także w zakresie zdrowia ludności mamy do czynienia ze zjawiskiem tzw. przejść epidemiologicznych. Wymienia się w historii ludzkości trzy okresy: (1) do neolitu, (2) od tego okresu do industralizacji w XVIII i XIX wie$\mathrm{ku}$, oraz (3) obecny, który nastąpił w XX wieku wraz z zastosowaniem antybiotyków (Barrett i inni 1998). Przejście jakie miało miejsce w okresie neolitu charakteryzowało się wzrostem śmiertelności z powodu chorób zakaźnych wobec zwiększonych skupisk ludności i kontaktów międzyludzkich, a także niskiej higieny komunalnej. Przejście spowodowane okresem industrializacji cechowało ograniczenie śmiertelności z powodu chorób zakaźnych, natomiast jej wzrost z powodu chorób przewlekłych. Trzecie przejście związane jest $\mathrm{z}$ zastosowaniem antybiotyków i mutacjami odpornych na nie mikroorganizmów. W ciągu ostatnich 30 lat zanotowano znaczne nasilenie występowania nowych, niewystępujących dotychczas chorób i spowodowanych nimi zgonów osób dorosłych. Szybkość narastanie owych nowych chorób wyprzedza możliwości przeciwdziałania i leczenia ich skutków. Jedynie w latach 1973-95 stwierdzono występowanie 29 
nowych patogenów (żywych czynników chorobotwórczych), do których zaliczyć należy HIV, a ostatnio wystąpiła nowa epidemia zwana SARS.

Powyższe modele dotyczące przejść demograficznych i epidemiologicznych wiążą się ze zmianami relacji populacji ludzkich ze środowiskiem. Mają one istotne znaczenie dla polityki ludnościowej, w profilaktyce chorób zakaźnych, w tym kształtowania środowiska oraz dla organizacji ochrony zdrowia $\mathrm{w}$ poszczególnych regionach.

(4) Problem zanieczyszczeń środowiskowych i ich wptywu na zdrowie człowieka

Zagadnienie dotyczy $\mathrm{z}$ jednej strony gromadzenia danych o zanieczyszczeniach powietrza, wody, gleby i żywności oraz higieny komunalnej, źródłach hałasów i wibracji przede wszystkim w miejscach zasiedlonych przez populacje ludzkie, z drugiej prowadzenia badań nad dopuszczalnymi granicami stężenia zanieczyszczeń z punktu widzenia wymogów i tolerancji ludzkiego organizmu. Całkowite wyeliminowanie zanieczyszczeń pyłowych, wodnych, akustycznych i tym podobnych nie jest możliwe, wobec wzrastających potrzeb i wynikającej stąd eksploatacji zasobów naturalnych, rozwoju przemysłu i komunikacji oraz intensyfikacji rolnictwa, szczególnie wobec przenoszenia się zanieczyszczeń poprzez granice krajów, a nawet z kontynentu na kontynent. Jak wspominaliśmy powyżej genetycznie uwarunkowane granice ludzkiej tolerancji są przypuszczalnie bardzo duże (Wolański i Siniarska 2002), ale przekraczanie granic wahań warunków środowiskowych $\mathrm{w}$ jakich dany organizm się rozwijał nie jest bezpieczne. Producenci dóbr materialnych są nastawieni na zyski, a nie inwestycje ekologiczne, które podrażają koszty produkcji. Regulacje prawne na ogół nie są wystarczające oraz są różnymi sposobami omijane. W związku z tym konieczne jest kształtowanie tzw. świadomości ekologicznej społeczeństwa z jednej strony celem indywidualnej współpracy w ochronie środowiska (np. poprzez odpowiednie składowanie odpadów i ich utylizację), z drugiej dla kontroli i wywierania nacisku na administrację celem egzekwowania ochrony środowiska od producentów i wyznaczania norm planistycznych.

Występuje wobec tego konieczność prowadzenia w zakresie ekologii człowieka monitoringu stanu biologicznego populacji, który jak wspominaliśmy jest jedynym obiektywnym miernikiem skutków zmian zachodzących $\mathrm{w}$ środowisku. Monitoring środowiska podaje jedynie wielkość zanieczyszczeń, z czego nie musi wynikać wpływ na organizm człowieka. Istotna jest bowiem często kombinacja współwystępujących elementów zanieczyszczeń, które mogą zmieniać i potęgować wpływy poszczególnych z nich. Inne metody (badanie odczuć ludności, zmiany w szacie roślinnej) są subiektywne z punktu widzenia zdrowia człowieka, lub świadczą o zachodzących zmianach jedynie pośrednio. Świadomość ekologiczna jest w Polsce niezbyt wysoka, szczególnie co do informacji o wpływie rozwoju ekonomicznego na stan środowiska, oraz bardzo nikła 
jeśli idzie o przekonania o możliwości wpływu obywateli na problemy ekologiczne (Wolański i Siniarska 2001).

(5) Sprawa przemian warunków bytowych i antagonizmów społecznych

Zagadnienie to stanowi podstawę szeregu badań nad rozwarstwieniem społecznym i wynikających stąd różnic w dostępie do zasobów naturalnych, źródeł surowców oraz udziału w podziale dochodu narodowego. Rozwarstwienie to przekłada się bowiem na różnice w warunkach bytowych, poziomie higieny, sposobie żywienia, obciążeniu wysiłkiem fizycznym oraz ekspozycji na zanieczyszczenia środowiska.

Już z danych z XIX wieku znane są przypadki antagonistycznych zależności pomiędzy włościanami a kupcami, w wyniku których gdy poborowi pochodzący ze wsi byli niżsi, wzrastała wysokość ciała ludności miejskiej, i na odwrót (Czekanowski 1948). W wyniku tego, że stan biologiczny ludności odzwierciedla warunki bytowe, jest on obiektywnym miernikiem dobroci owych warunków (Wolański 2003a, b). W szczególności celowi temu służą wspomniane poprzednio pozytywne mierniki zdrowia dzieci i młodzieży.

W Polsce powojennej długość trwania życia była początkowo dłuższa w miastach, jednak z chwilą przekroczenia 50\% ludności zamieszkującej miasta, od roku 1964 mężczyżni, a od 1973 kobiety żyły dłużej na wsiach. Jednak po zmianach ustrojowych 1989 roku, od roku 1994 ponownie dłużej żyją mężczyźni zamieszkujący miasta, a zjawisko to przypuszczalnie wkrótce dotyczyć będzie kobiet (ryc. 3).

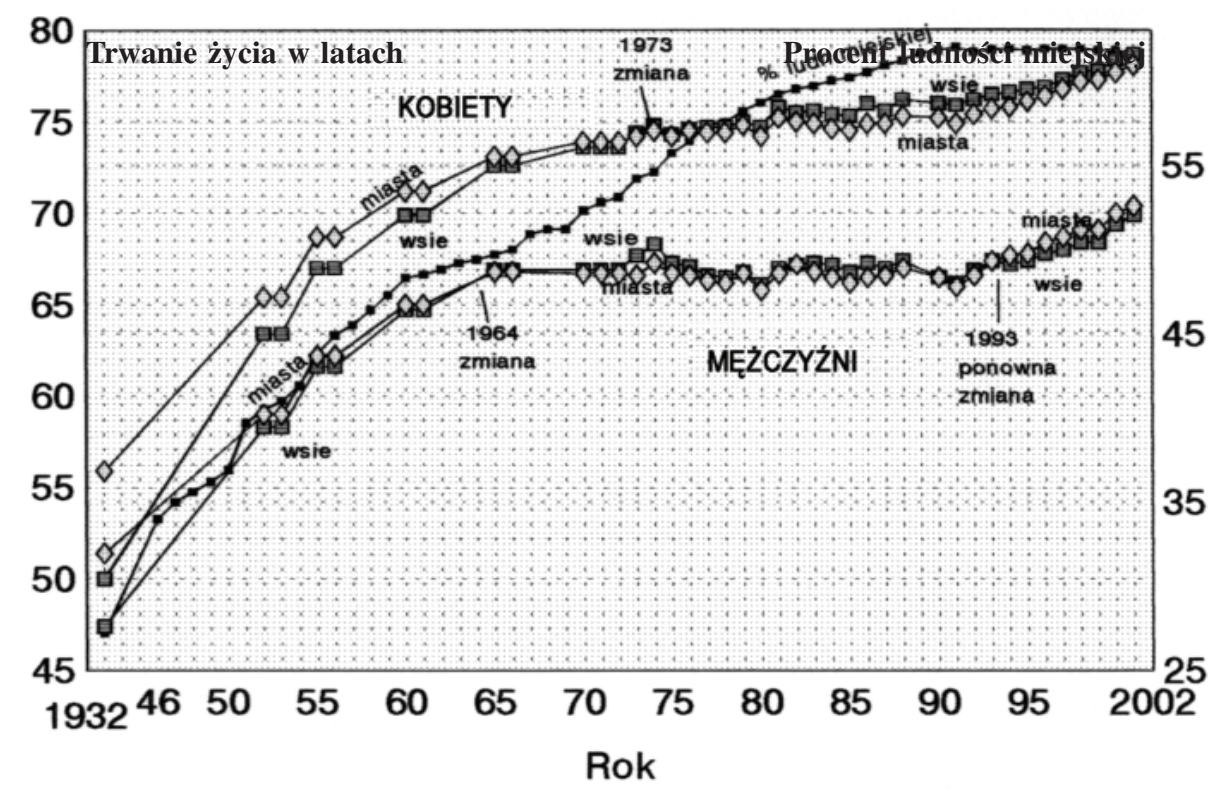

Ryc. 3. Przeciętne trwanie życia ludności w miastach i na wsiach a procent ludności zamieszkującej miasta w Polsce w latach 1932-2001 
Badania tego typu mają więc wielkie znaczenie praktyczne dla oceny stanu zdrowia populacji ludzkich oraz działań profilaktycznych. Są one ściśle powiązane z socjologią i epidemiologią.

(6) Ewolucyjne i behawioralne problemy ekologii człowieka

Zagadnienia te ostatnio bardzo modne w odniesieniu do człowieka, nawiązują do kierunku badań zwanych od ćwierćwiecza socjobiologią, a dotyczących badań nad ewolucją zachowania się zwierząt (Pianka 1981, Trivers 1985). W odniesieniu do człowieka chodzi tutaj o zachowania społeczne i narzędziowe, które były podstawą powstania kultury i ewolucji społecznej.

Badania te w niewielkim stopniu nawiązują do problemów ochrony środowiska, aczkolwiek jako zachowania mające na celu pozyskiwania żywności, mają pośredni wpływ na środowisko naturalne.

\section{Dydaktyka}

Zakres wykładów z ekologii człowieka obejmuje następujące działy, które podano na przykładzie wykładów prowadzonych od roku akademickiego 2000/2001 na Uniwersytecie Kardynała S. Wyszyńskiego w Warszawie, oraz jakie zawiera znajdujący się $\mathrm{w}$ druku podręcznik (Wolański 2003): Czym jest ekologia człowieka. Metodologia ekologii człowieka. Strategie przeżycia. Uwarunkowania i czynniki życia człowieka. Adjustacje. Odwracalne dostosowywania organizmu. Nieodwracalne dostosowania rozwojowe. Przystosowania na poziomie populacji. Adaptacja genetyczna. Stan biologiczny osobnika i populacji. Powstanie człowieka, jego ewolucja i zmienność. Antropogeografia i fizjologia środowiskowa. Systemy osadnicze. Urbicenozy. Region, osiedle i rodzina jako środowisko życia i rozwoju człowieka. Kulturowe przystosowania do życia w poszczególnych biocenozach. Cywilizacja jako strategia adaptacyjna. Cywilizacja miejsko-przemysłowa a problemy środowiska. Ekologia żywienia. Ekologia zdrowia i choroby. Przyszłość - Społeczeństwo postindustrialne - Globalizacja (Perspektywy ekologii czlowieka w zakresie nauk biomedycznych. Świadomość ekologiczna. Wychowanie do środowiska. Bioetyka w aspekcie ekologicznym).

\section{Podsumowanie}

W przeszłości badania rozumiane jako ekologia człowieka były niekompletne, badano jeden aspekt (a nawet jedną cechę) natury człowieka i wybrany element jego środowiska. Nie zważano na istniejące interakcje zarówno między biologiczną i społeczno-kulturową naturą człowieka, między przyrodniczymi i sztucznymi (technicznymi) warunkami środowiska oraz aktywną i pasywną rolę jednych i drugich. 
Współczesne badania w zakresie EC jako nauki transdyscplinarnej nie istnieją bez badań biologicznych mechanizmów przystosowywania się osobników i populacji ludzkich oraz kulturowych form przystosowania społeczności ludzkich do środowiska $\mathrm{z}$ równoczesnym badaniem tego środowiska $\mathrm{w}$ jakim populacje te się rozwijały $\mathrm{w}$ procesie ontogenezy $\mathrm{i}$ filogenezy, a więc jako ekosystemu. Wprowadzenie do EC narzędzi matematycznych umożliwiło systemowe badania prowadzące do ujęć syntetycznych. Analiza czynnikowa pozwoliła na wyodrębnienie głównych składowych (latent factors) zarówno właściwości środowiska jak i poszczególnych organizmów lub populacji ludzkich. Owe ukryte czynniki mają ten walor, że nie są ze sobą skorelowane. Różne formy regresji wielorakiej i analizy wariancji pozwoliły na zrozumienie i oszacowanie zależności między środowiskowymi elementami przyrody i społeczeństwa oraz między biologiczną i społeczno-kulturową istotą człowieczeństwa.

$\mathrm{Na}$ ile ekologia (geoekologia i bioekologia) jest naukową podstawą ochrony przyrody, to ekologia człowieka jest naukową podstawą ochrony środowiska życia człowieka i samego człowieka jako gatunku biologicznego, który jest specyficzny swoją kulturą. Ekologia człowieka (poza poziomem populacyjnym) zajmuje się także przystosowaniem człowieka na poziomie osobniczym (fizjologią środowiskową) oraz kulturowymi zachowaniami przystosowawczymi (antropologią kulturową). Owa część ekologii człowieka dotycząca zmian poszczególnych osób (ich organizmu, psychiki, zachowań kulturowych) ma podstawowe znaczenie dla oceny zmian $\mathrm{w}$ środowisku życia ludzi. W przeszłości przystosowanie do środowiska zachodziło na poziomie populacji, dobór naturalny eliminował osobniki nieprzystosowane. Współcześnie dzięki kulturze (w szczególności medycynie, oświacie i opiece społecznej) taka selekcja w cywilizowanych populacjach nie ma miejsca. Ocenę wartości środowiska dokonuje się więc nie na podstawie wskaźników negatywnych (umieralności i śmiertelności), lecz pozytywnych wskaźników stanu biologicznego poszczególnych członków społeczeństwa. Termin ekologia człowieka jest więc uzasadniony, a jej teoriopoznawcza i praktyczna rola nie ulega wątpliwości.

U początków tworzenia Międzynarodowej Komisji Ekologii Człowieka (CHE/IUAES), postawiono pytanie, czy ekologia człowieka jest nauką czy punktem widzenia (Wolański 1987b). Dzisiaj przychodzi postawić tę kwestię ponownie. Z perspektywy 20 lat można powiedzieć, że badania nad człowiekiem w kontekście środowiskowym są nauką, jednak dla nauk ekologicznych czy biologii środowiskowej jest to pewien punkt widzenia. Punkt widzenia o poważnym znaczeniu dla przyszłości tak ludzkości jak i naszej planety. Ten punkt widzenia zarówno w aspekcie ewolucyjnym (ekologia ewolucyjna i behawioralna), jak i współczesnych populacji (ekologia krajobrazu i fizjologia środowiskowa) stanowią perspektywę przeżywającej kryzys bioekologii. Instytut Ekologii PAN uległ 
likwidacji nie tylko z powodu trudności finansowych nauki polskiej i niegospodarności jego kierownictwa, ale także z powodu nieumiejętności powiązania $\mathrm{z}$ problemami praktyki: ochrony środowiska i roli populacji ludzkich w przekształcaniu przyrody i jej wtórnego wpływu na nasze zdrowie i dobrostan. Rolą nauki jest przede wszystkim użyteczność dla człowieka, o czym zapomniano. Chodzi tu zarówno o użytkowość w sensie materialnym, jak przede wszystkim o poszerzanie horyzontów myślowych i szerzenie oświaty. W zakresie ekologii dotyczy to kształtowania świadomości ekologicznej i wychowania w poszanowaniu zasobów i walorów środowiska, ale bioekologia wyłączyła ten problem ze swego zakresu badań. Temu służy ekologia człowieka i na tym polega jej społeczna rola.

\section{Podziękowania}

$\mathrm{W}$ trakcie opracowania niniejszego artykuły korzystano z materiałów zebranych $\mathrm{w}$ trakcie realizacji wielu grantów o których wspomniano $\mathrm{w}$ tekście, jak również aktualnego grantu meksykańskiego KBN (CONACyT nr 26469H). Autorzy wyrażają także podziękowania za uwagi do pierwotnej wersji artykułu prof. Maciejowi Hennebergowi, prorektorowi Uniwersytetu w Adelaidzie (Australia).

\section{Literatura}

Aiello L.C., Wells J.C.K., 2002 - Energetics and the evolution of the genus Homo. Annual Revue in Anthropology, 31:323-38.

BAKER P.T., 1988 - Human Adaptability. In „Human Biology. An introduction to human evolution, variation, growth, and adaptability" Pod redakcją G.H. Harrisona i innych, 3-cie wydanie, Oxford Science Publications, Oxford, New York, Tokyo (str. 439-547).

BAKER P.T., 1996 - Adventures in human population biology. Annual Review in Anthropology, 25:1-18,

Barrett R., Kuzawa C.W., McDade T., Armelagos G.J., 1998 - Emerging and re-emerging infectious diseases: The third edpidemiologic transition. Annual Review of Anthropology. 27:247-71.

Bogin B., 1999 - Patterns of human growth. Second ed., Cambridge University Press, Cambridge.

Boyden S., Millar S., Newcombe K., O’Neill B., 1981 - The ecology of a city and its people. The case of Hong Kong. Australian National University Press, Canberra.

CAMpBell B., 1995 - Ekologia człowieka. Historia naszego miejsca w przyrodzie od prehistorii do czasów wspótczesnych. Wydawnictwo Naukowe PWN, Warszawa.

CZeKanowski J., 1948 - Zagadnienia antropologii (Zarys antropologii teoretycznej). Księgarnia Naukowa Szczęsny, Toruń.

Ehrlich P.R., Ehrlich A.H., 1970 - Population, Resources, Environment. Issues in Human Ecology. Freeman \& Co, San Francisco. 
Ehrlich P.R., Ehrlich A.H., Holdren J.P., 1975 - Humanoecologie. Der Mensch im Zentrum einer neue Wissenschaft. Berlin.

Ehrlich P., Ehrlich A., Holdren J., 1977 - Ecoscience: Population, Resources, Environment. 3rd edition, Freeman \& Co, San Francisco.

GórNicKi B., 1963 - Instytut Matki i Dziecka na tle celów i zadań instytutów naukowo-badawczych. Prace i Materiaty Naukowe IMD. 1:7-21.

HenNeberg M., 1976 - Reproductive possibilities and estimations of the biological dynamics of earlier human populations, Journal of Human Evolution, 5: 41-48.

Henneberg M., Piontek J., 1975 - Biological state index of human groups, Przeglad Antropologiczny, 41: 191-201.

McElroy A., Townsend P.K., 1989 - Medical anthropology in ecological perspective. Westview Press, Boulder, San Francisco and London.

Miller G.T., 1985 - Living in the Environment. An Introduction to Invironmental Science. 4-th edition, Wadsworth Publishing Comp., Belmont.

Moran E.F., 1982 - Human Adaptability. An Introduction to Ecological Anthropology. Westview Press, Boulder.

Odum H.T., 1971 - Environment, Power, and Society. Wiley Interscience, New York.

Odum E.P., 1982 - Podstawy ekologii. Wyd. 3. PIWRiL, Warszawa.

Odum H.T., Odum E.C., 1980 - Energy Basis for Man and Nature. McGraw-Hill, New York.

PawŁowski B., 1998 - Why are human newborns so big and fat?. Human Evolution: 13: 65-72.

PAwŁowski B., 1999 - Permanent breasts as a side effect of subcutaneous fat tissue increase in human evolution, Homo, 50(2):149-162.

PYżuk M., Wolański N., 1972 - Układ oddychania i krążenia u dzieci w różnorodnych warunkach środowiskowych. PWN, Warszawa.

SARGEnT F., 1983 - Human Ecology. A guide to information sources. Gale Research Company, Detroit.

Siniarska A., Dickinson F., 1996 - Annotated bibliography in human ecology. Vol. 1. Kamla-Raj Enterprises. Delhi. (350 stron).

Siniarska A., Wolański N. (redaktorzy), 2000 - Ecology of Aging. Kamla-Raj Enterprises, Delhi. (216 stron).

SinIARSKA A., ZieliŃSKA A., 2002 - Ethnic differences in body build and maturation of 6-18 years old girls from Merida, Yucatan, Mexico. Collegium Antropologicum, 26(Supplement):189-190.

Trivers R., 1985 - Social Evolution. Benjamin-Cummings Publishing Co, Menlo Park.

Webster's New Universal Unabridged.Dictionery, Dorset \& Baber, New York 1979

Weiner J.S., 1964 - Human Ecology. In „Human Biology” Pod red. G.H.Harrisona i innych, Oxford University Press, New York.

Wolański N., 1976 - Zmieniający się Człowiek. Biblioteka Problemów, PWN, Warszawa. (564 stron).

Wolański N., Zmiany środowiskowe a rozwój biologiczny człowieka. Ossolineum, Wrocław 1983. (190 stron).

Wolański N., 1985 - Ekologia człowieka a problemy urbanistyki. Towarzystwo Wiedzy Powszechnej, Warszawa (131 stron).

Wolański N. (redaktor), 1987a - Czynniki Rozwoju Człowieka. Wstęp do Ekologii Człowieka. 3cie wydanie, PWN, Warszawa. (704 strony)

Wolański N., 1987b - Human ecology - Science or point of view? In: „Prospecting Human Ecology", 1st Intern. Conf. on Human Ecology, ed. by C. Bernis and M. Sandin: 13-70. Universidad Autonoma de Madrid, Madrid.

WolańSKi N., 1990 - Glossary of Terms and Annotated Bibliography for Human Ecology, CHE/ IUAES, Warszawa. (62 stron).

Wolański N., 2002 - Modernizm, adaptation and global bioethics, Global Bioethics, 15(1-2).

Wolański N., w druku (2003a) - Rozwój Biologiczny Człowieka (Podstawy auksologii). Wydanie 7. Wydawnictwo Naukowe PWN. 
Wolański N., w druku (2003b) - Ekologia Cztowieka (Nisza biokulturowa w czasie i przestrzeni). Wydawnictwo Naukowe PWN.

Wolański N. I Bogin B. (redaktorzy), 1996 - The Family as an Environment for Human Development. Kamla-Raj Enterprises, Delhi. (203 strony).

Wolański N., Sintarska A. (redaktorzy), 1982 - Ekologia Populacji Ludzkich. Ossolineum, Wrocław.

Wolański N., Siniarska A. (redaktorzy), 1983 - Biomedyczne Podstawy Rozwoju i Wychowania, wyd. 2, PWN, Warszawa.

Wolański N., Siniarska A., 2001a - Wychowanie do środowiska w świetle ekologii człowieka. W „Edukacja ekologiczna na progu XXI wieku. Stan-możliwości-programy”, 63-85, Verbinum, Warszawa.

Wolański N, Siniarska A., April 2001b - Assesing the biological status of human populations. Current Anthropology, 42(2):301-308.

Wolański N., SiniarsKa A., 2002 - Możliwości adaptacyjne człowieka a problemy bioetyczne środowiska jego życia. Studia Philosophiae Christianae, UKSW, 38(2):161-176.

Wolański N., Szemik M. (redaktorzy), 1984 - Industrialization Impact on Man. Studies in $\mathrm{Hu}$ man Ecology, 5.

Young G.L., 1974 - Human ecology as an interdisciplinary concept: A critical inquiry. Advances in Ecological Research, 8:1-105, Academic Press Inc., London.

Young G.L., 1983 - Origins of Human Ecology. Benchmark Papers in Ecology, 12, Hutchinson Ross Publ.Comp., Stroudsbourg.

Young G.L., 1989 - A conceptual framework for an interdisciplinary human ecology. Acta Oecologiae Hominis, 1, Lund.

\section{What is a Contemporary Human Ecology}

\section{SUMMARY}

Human ecology is a synthetic transdiciplinary science concerned with human life and culture as a dynamic component of ecosystems. Human ecology (HE) synthesizes parts of the knowledge of several classical disciplines in a specific way. The essence of $\mathrm{HE}$ is the interaction between humans and the total environment. While the whole idea of HE is originated in anthropology, the first time the term "human ecology" was used in geography and next in sociology. Historically, in its monodisciplinary stage of development, the problems of several classical disciplines related to man and environment were called human ecology. The next stage was the multidisciplinary state, related to IBP (International Biological Programme), presenting a patchwork of information without syntheses. Contemporary HE offers more than a patchwork of knowledge and is based on system theory. In human ecology, human evolution and ontogeny are understood as processes of adaptation and adjustment to the environment. HE may be considered to have two parallel foci: an academic HE as a scientific discipline, and an action oriented HE (environmental engineering, preservation, education, and health protection against environmental deterioration). In HE several divisions and research perspectives may be defined: 1. Philosophical problems of HE; 2. Social and biological problems of human environment; 3. Environmental problems of human biology and 4 . Cultural adaptive behaviour. 